\title{
Progress Report for Diffusion Welding of the NGNP Process Application Heat Exchangers
}

R. E. Mizia, D. E. Clark, M. V. Glazoff, T. E. Lister, T. L. Trowbridge April 2011

The INL is a

U.S. Department of Energy

National Laboratory

operated by

Battelle Energy Alliance

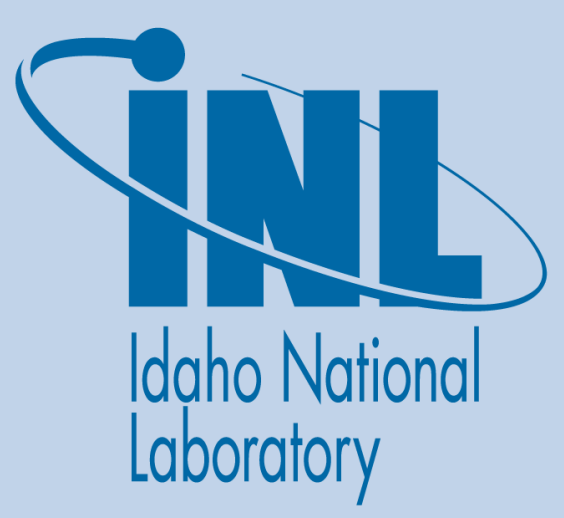

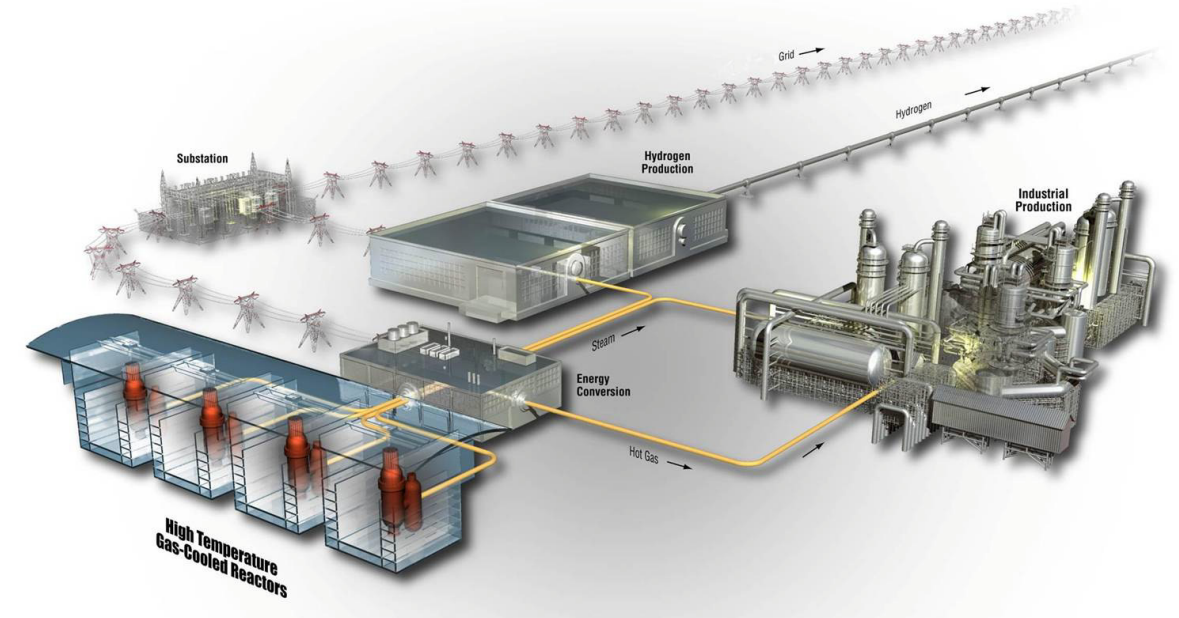




\section{DISCLAIMER}

This information was prepared as an account of work sponsored by an agency of the U.S. Government. Neither the U.S. Government nor any agency thereof, nor any of their employees, makes any warranty, expressed or implied, or assumes any legal liability or responsibility for the accuracy, completeness, or usefulness, of any information, apparatus, product, or process disclosed, or represents that its use would not infringe privately owned rights. References herein to any specific commercial product, process, or service by trade name, trade mark, manufacturer, or otherwise, does not necessarily constitute or imply its endorsement, recommendation, or favoring by the U.S. Government or any agency thereof. The views and opinions of authors expressed herein do not necessarily state or reflect those of the U.S. Government or any agency thereof. 


\title{
Progress Report for Diffusion Welding of the NGNP Process Application Heat Exchangers
}

\author{
R. E. Mizia, D. E. Clark, M. V. Glazoff, T. E. Lister, T. L. Trowbridge
}

April 2011

Idaho National Laboratory

Next Generation Nuclear Plant Project

Idaho Falls, Idaho 83415

Prepared for the

U.S. Department of Energy

Office of Nuclear Energy

Under DOE Idaho Operations Office

Contract DE-AC07-05ID14517 



\section{Next Generation Nuclear Plant Project}

\section{Progress Report for Diffusion Welding of the NGNP Process Application Heat Exchangers}

INL/EXT-11-21817

April 2011

Approved by:

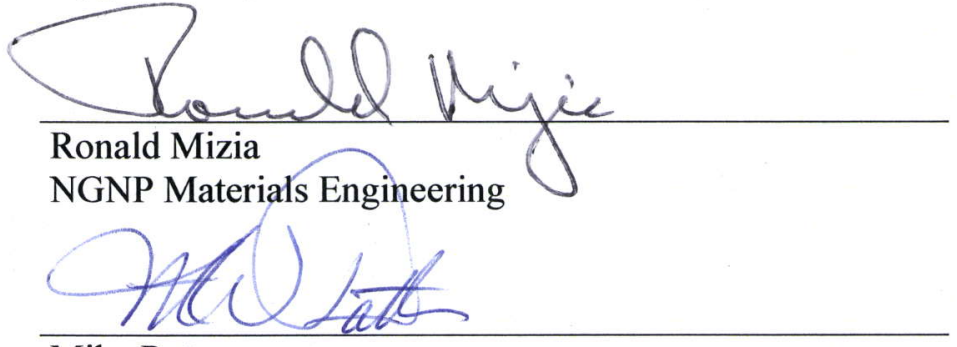

Mike Patterson

NGNP Progess Heat Applications Manager

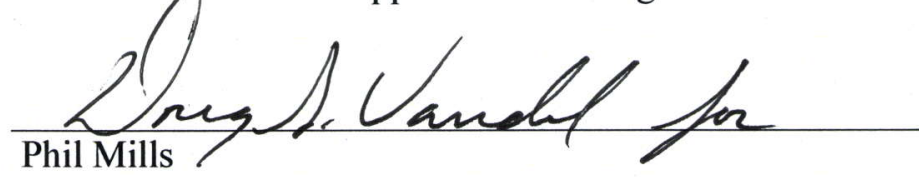

NGNP Engineering Director
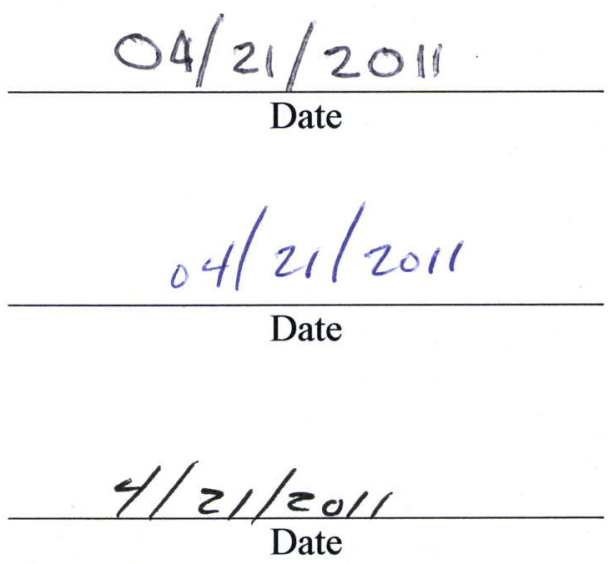



\section{SUMMARY}

The U.S. Department of Energy selected the high temperature gas-cooled reactor as the basis for the Next Generation Nuclear Plant (NGNP). The NGNP will demonstrate the use of nuclear power for electricity, hydrogen production, and process heat applications. The NGNP Project is currently investigating the use of metallic, diffusion welded, compact heat exchangers to transfer heat from the primary (reactor side) heat transport system to the secondary heat transport system. An intermediate heat exchanger will transfer this heat to downstream applications such as hydrogen production, process heat, and electricity generation. The channeled plates that make up the heat transfer surfaces of the intermediate heat exchanger will have to be assembled into an array by diffusion welding. This report describes the preliminary results of a scoping study that evaluated the diffusion welding process parameters and the resultant mechanical properties of diffusion welded joints using Alloy $800 \mathrm{H}$. The long-term goal of the program is to progress towards demonstration of small heat exchanger unit cells fabricated with diffusion welds. Demonstration through mechanical testing of the unit cells will support American Society of Mechanical Engineers' rules and standards development, reduce technical risk, and provide proof of concept for heat exchanger fabrication methods needed to deploy heat exchangers in several potential NGNP configurations.1

Researchers also evaluated the usefulness of modern thermodynamic and diffusion computational tools (Thermo-Calc and Dictra) in optimizing the parameters for diffusion welding of Alloy $800 \mathrm{H}$. The modeling efforts suggested a temperature of $1150^{\circ} \mathrm{C}$ for 1 hour with an applied pressure of $5 \mathrm{MPa}$ using $15 \mu \mathrm{m}$ nickel foil as joint filler to reduce chromium oxidation on the welded surfaces. Good agreement between modeled and experimentally determined concentration gradients was achieved. 


\section{CONTENTS}

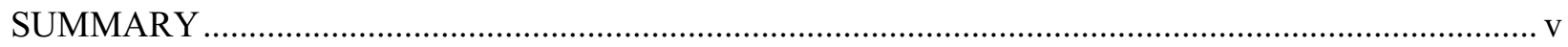

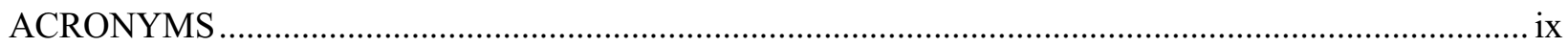

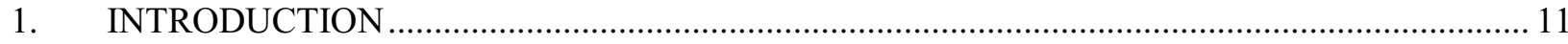

2. EXPERIMENTAL TECHNIQUES AND SIMULATION METHODS ...................................... 13

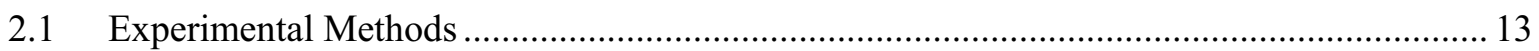

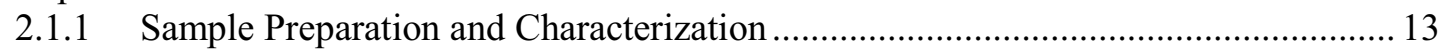

2.1.2 Gleeble Thermomechanical System for Diffusion Welding ................................... 13

2.1.3 Optical Microscopy, Scanning Electron Microscopy, and Energy Dispersive X-ray Spectroscopy Analyses ............................................................................. 15

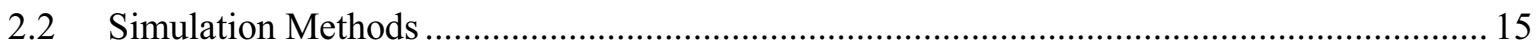

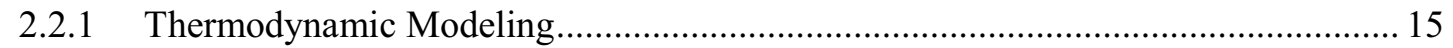

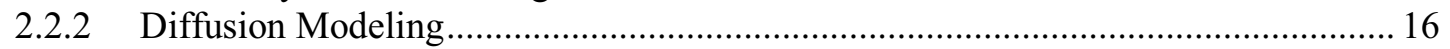

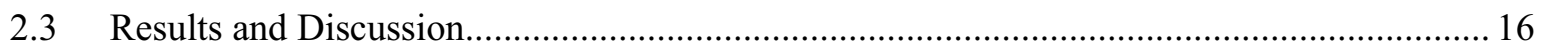

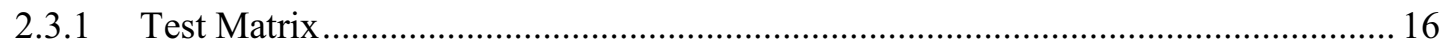

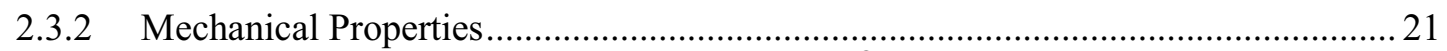

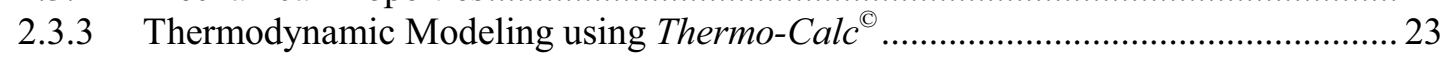

2.3.4 Dictra Modeling of the $800 \mathrm{H} / \mathrm{Ni} / 800 \mathrm{H}$ Diffusion Couple, Comparison to

Experiment, and Optimization of Welding Conditions............................................ 28

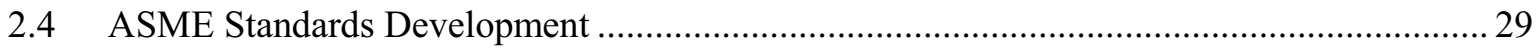

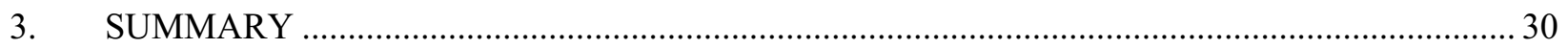

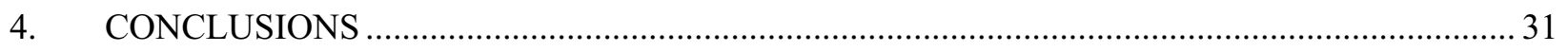

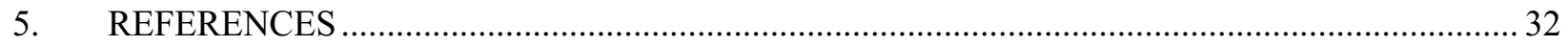

\section{FIGURES}

Figure 1. Gleeble system: (a) General view of the Gleeble system with a specimen in it;

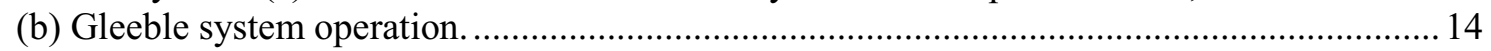

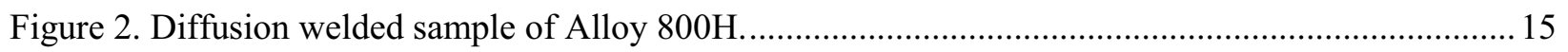

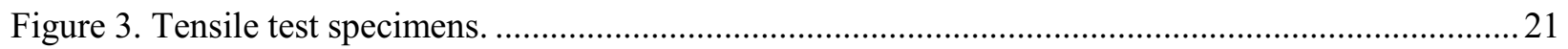

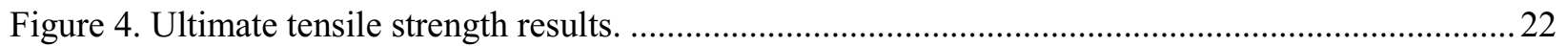

Figure 5. Phase composition of Alloys $800 \mathrm{H}$ as a function of temperature............................................ 24

Figure 6. SEM image of an Alloy $800 \mathrm{H}$ sample heat treated at $1150^{\circ} \mathrm{C}$ for 3 hours and then

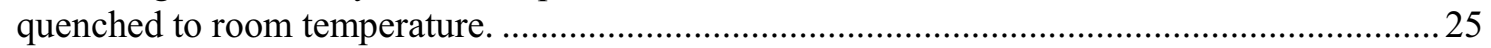

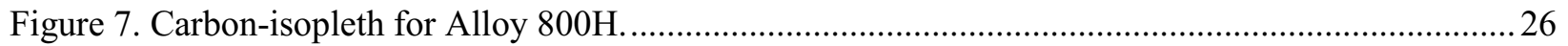

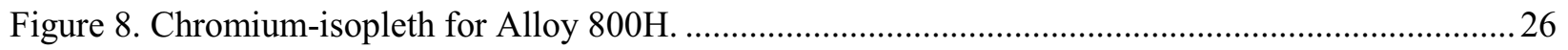

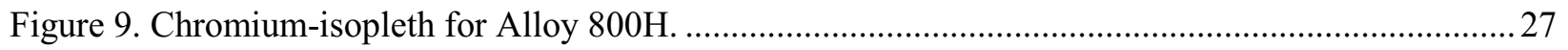

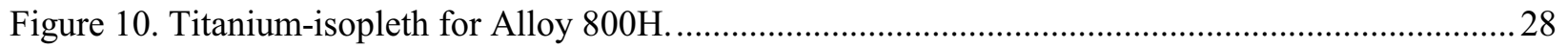


Figure 11. Comparison of model and experimental data (SEM/EDS analyses) for diffusion bonded specimen comprised of Alloy $800 \mathrm{H}$ (15 $\mu \mathrm{m}$ of nickel foil filler) and Alloy $800 \mathrm{H}$. The duration of process was $3,600 \mathrm{sec}$ at compressive pressure of $5 \mathrm{MPa}$ and temperature $1150^{\circ} \mathrm{C}$. Dictra modeling was done for the same conditions.

\section{TABLES}

Table 1. Chemical composition of Alloy $800 \mathrm{H}$ used in diffusion-welding experiments (data are

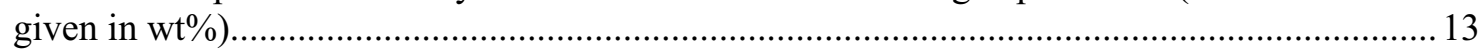

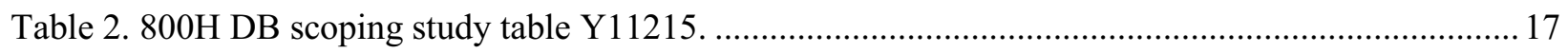

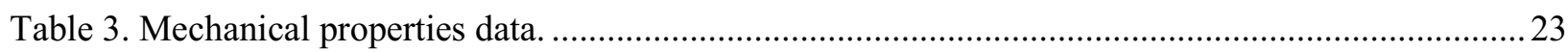




\section{ACRONYMS}

ASME American Society of Mechanical Engineers

EDS energy dispersive spectrometry

EDX energy dispersive x-ray

HTGR high temperature gas-cooled reactor

HTTR High-Temperature Engineering Test Reactor

IHX intermediate heat exchanger

INL Idaho National Laboratory

NGNP Next Generation Nuclear Plant

SEM scanning electron microscope

VHTR very high-temperature reactor

WDS wavelength dispersive spectrometry 


\section{Progress Report for Diffusion Welding of the NGNP Process Application Heat Exchangers}

\section{INTRODUCTION}

The U.S. Department of Energy selected a high temperature gas-cooled reactor (HTGR) as the basis for the Next Generation Nuclear Plant (NGNP). The NGNP Project will demonstrate the use of nuclear power to generate electricity, produce hydrogen, and provide process heat for other applications. The NGNP will be powered by a graphite moderated, helium cooled, prismatic or pebble bed, thermal neutron spectrum reactor that uses very high burn-up, low-enriched uranium, tristructural-isotopic-coated fuel. The plant design will have a projected service life of 60 years. The plant size, reactor thermal power, and core configuration will ensure passive decay heat removal without fuel damage or radioactive material releases during accidents.

The basic technology for the NGNP was established in earlier HTGR plants, including DRAGON, Peach Bottom, Albeitsgemeinschaft Versuchsreaktor, Thorium Hochtemperatur Reaktor, and Fort St. Vrain. These reactor designs represent two design categories: the pebble bed modular reactor and the prismatic modular reactor. The Japanese High-Temperature Engineering Test Reactor (HTTR) and Chinese High-Temperature Reactor (HTR-10) are currently demonstrating the feasibility of the reactor components and materials needed for a very high-temperature reactor (VHTR).

An important component of some VHTR designs is the intermediate heat exchanger (IHX) located in the heat transport system, which transfers heat from the primary heat transport system to the secondary heat transport system which carries the heat to the downstream applications. The compact heat exchanger design concepts that will require the development of diffusion welding for the joining of plate stacks are:

- Printed-circuit heat exchanger

- Plate-fin heat exchanger

- Formed-plate heat exchanger

- Plate-machined heat exchanger

- Plate-stamped heat exchanger.

Diffusion welding of superalloys, including Alloy $800 \mathrm{H}$, is a critical operation in the manufacture of components for the aerospace and nuclear industries. ${ }^{1,2,3}$ It involves practically all of the phenomena studied by physical and mechanical metallurgy: control of grain growth and crystallographic texture across the weld interface; diffusion processes and phase transformations resulting in concentration profiles of different components and precipitates; and the prevention of high-temperature oxidation of different components (especially chromium). It is also necessary to optimize the welding temperature and the duration of exposure, applied compressive stress, heat-up schedule, and post-welding heat treatment. Even though solid-state diffusion is a relatively stable and predictable phenomenon, significant parameters are involved in the diffusion welding of real components in real alloys, and process development can require hundreds of expensive experiments, their mathematical planning, and the application of multiple linear regressions or artificial neural networks to achieve reliable results. ${ }^{4}$

The diffusion welding test program is described in Idaho National Laboratory (INL) PLN-3565. ${ }^{5}$ The diffusion welds were made in a Gleeble Test System. The material of construction used in this test program is Alloy $800 \mathrm{H}$, which is based on recommendations made in the NGNP Technology Development Roadmap. ${ }^{6}$ 
New software tools were applied to this program. During the last 15 years, powerful thermodynamic, diffusion, and finite element simulations (coupled to a new, state-of-the-art plasticity model) have come of age. ${ }^{7,8,9,10,11,12}$ These computational tools-Thermo-Calc and Dictra-were used in the program to predict the metallurgical phases present in the diffusion welded joint at the diffusion welding temperature and at compact heat exchanger operating temperatures. 


\section{EXPERIMENTAL TECHNIQUES AND SIMULATION METHODS}

\subsection{Experimental Methods}

\subsubsection{Sample Preparation and Characterization}

\subsubsection{Material}

The sample material, $0.5 \mathrm{in}$. diameter Alloy $800 \mathrm{H}$ round bar (UNS 80810/80811), for fabrication of the diffusion welded specimens was purchased to the requirements of ASTM International B408. ${ }^{13}$ The chemical composition results of Huntington Alloys Corporation Heat (HH3507AR) are given in Table 1. In addition to alloying elements, a small amount ( $\sim 0.001 \mathrm{wt} \%)$ of sulfur impurity was found.

Table 1. Chemical composition of Alloy $800 \mathrm{H}$ used in diffusion-welding experiments (data are given in wt\%).

\begin{tabular}{|r|c|c|c|c|c|c|c|c|c|c|c|c|}
\hline $\mathbf{C}$ & $\mathbf{M n}$ & $\mathbf{F e}$ & $\mathbf{S i}$ & $\mathbf{C u}$ & $\mathbf{N i}$ & $\mathbf{C r}$ & $\mathbf{A l}$ & $\mathbf{T i}$ & $\mathbf{C o}$ & $\mathbf{N}$ & $\mathbf{N b}$ & $\mathbf{S}$ \\
\hline 0.08 & 1.02 & 45.57 & 0.31 & 0.18 & 32.16 & 19.59 & 0.46 & 0.55 & 0.08 & 0.007 & 0.053 & 0.001 \\
\hline
\end{tabular}

\subsubsection{Diffusion Weld Sample Preparation}

The basic test procedure developed during the scoping studies involved the following process:

1. Prepare specimen ends with 600 or 800 grit grinding.

2. Prepare specimens further, as needed (e.g., nickel plating).

3. Weld thermocouple on one piece near interface.

4. Place mating parts in Gleeble jaws and manually adjust for alignment, including nickel interlayers (foils or plating) as appropriate.

5. Evacuate chamber to mid- $10^{-4}$ Torr range (about 15 minutes).

6. Initiate Gleeble program, which applies force and heats to bonding temperature.

7. Manually fine-tune air ram pressure to maintain desired stress on specimen during bonding cycle (typically 3 hours).

8. Remove specimens after cooling.

\subsubsection{Gleeble Thermomechanical System for Diffusion Welding}

This diffusion welding investigation evaluated diffusion welding with no filler metal addition. It also evaluated filler metal additions to the faying (bonded) surfaces by the use of nickel plating, or a nickel foil interlayer as a filler material.

The diffusion bonds were performed using a Gleeble ${ }^{\mathrm{TM}} 3500$ System, ${ }^{\mathrm{a}}$ a general-purpose servohydraulic thermomechanical testing device that can perform physical simulation of metallurgical processes as shown in Figure 1-(a). The system can heat or cool specimens at rates up to $10,000^{\circ} \mathrm{C} /$ second $^{2}$ and apply forces up to 20 tons at a rate of up to $1,000 \mathrm{~mm} / \mathrm{second}$. Figure 1-(b) illustrates the operation of the Gleeble system for diffusion welding.

a. Dynamic Systems, Inc., Poestenkill, New York. 

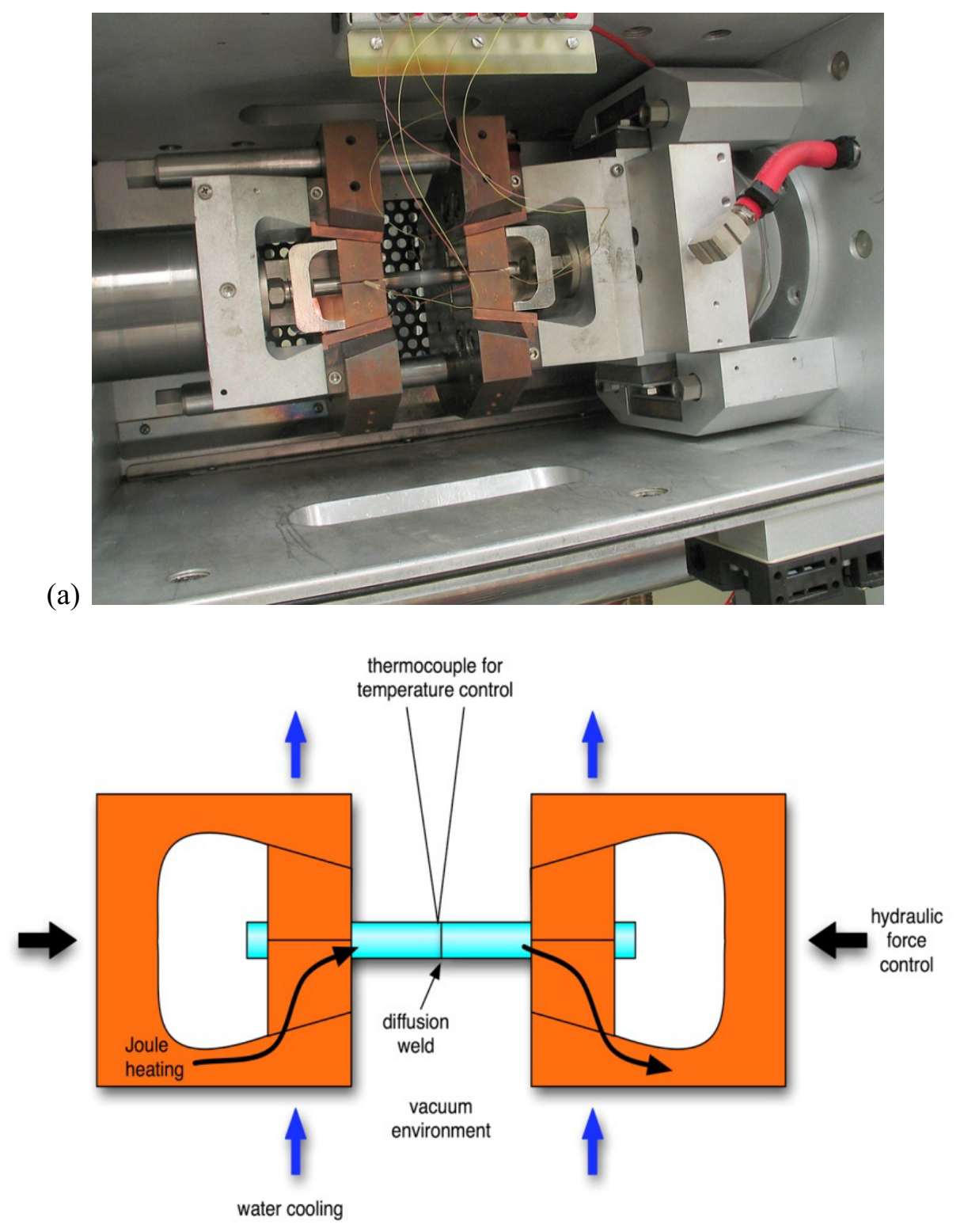

(b)

Figure 1. Gleeble system: (a) General view of the Gleeble system with a specimen in it; (b) Gleeble system operation.

Diffusion welding is a slow process with a relatively low applied stress that is well within the Gleeble's capacity, and the digital feedback loops are effective for precise control of the process. The Gleeble also provides a vacuum/controlled atmosphere chamber, which is required to control surface oxidation during the diffusion welding process. Heat is provided by Joule heating of the specimen held in water-cooled grips with feedback control provided by an attached thermocouple.

The Gleeble System is able to reproducibly create the thermal and mechanical components of the diffusion welding process. The Alloy $800 \mathrm{H}$ test material near the weld interface is exposed to the same thermal and mechanical history that it would see in the full-scale diffusion-welding process, which might be accomplished in a vacuum hot press or hot isostatic press. 


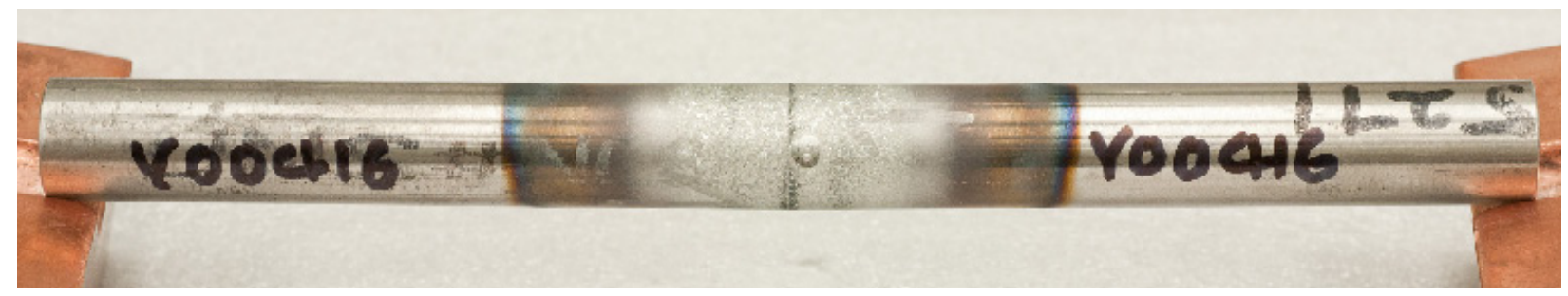

Figure 2. Diffusion welded sample of Alloy $800 \mathrm{H}$.

\subsubsection{Mechanical Properties Testing}

Duplicate specimens were made for tensile testing, and a tensile specimen was designed nominally based on the ASTM International E-8 specimen. ${ }^{14}$

\subsubsection{Optical Microscopy, Scanning Electron Microscopy, and Energy Dispersive X-ray Spectroscopy Analyses}

Metallography was performed by taking a cylindrical section and slicing it longitudinally. One half was mounted and prepared for microstructural examination and the other half reserved for further testing, such as eventual exposure in the high temperature helium test loop. ${ }^{15}$ Samples of diffusion bonded specimens were prepared for microstructural characterization using standard metallographic procedures, with a final polishing step of $0.04 \mu \mathrm{m}$ silica in a vibratory polisher. Microstructures were developed for observation with a multistep etching process. The first step is an immersion in $\mathrm{HCl}$ (concentrated) for 5 to 10 seconds, followed by a methanol rinse, and a final step of immersion in a $2 \%$ bromine etchant ( $1 \mathrm{ml} \mathrm{Br}, 50 \mathrm{ml}$ methanol) for 5 to 10 seconds.

Microstructural imaging was conducted by light optical microscopy and scanning electron microscopy (SEM) using both secondary electron hand backscattered electron imaging modes. The SEM analysis was conducted on a high resolution FEI Quanta $650 \mathrm{FEG}^{\mathrm{TM}}$ SEM equipped with a field emission gun. This system is equipped with an EDAX ${ }^{\mathrm{TM}}$ Trident integrated materials characterization system which includes energy dispersive spectrometry (EDS), electron backscattered diffraction, and wavelength dispersive spectrometry (WDS) capabilities. For the chemical analysis used in this investigation, EDS is considered a semiquantitative technique and WDS is considered a quantitative technique. The SEM imaging and WDS elemental analysis were performed at an accelerating voltage of $20 \mathrm{kV}$.

\subsection{Simulation Methods}

\subsubsection{Thermodynamic Modeling}

The construction of isopleths and initial assessment of thermodynamic equilibrium to establish phase composition of the Alloy $800 \mathrm{H}$ was done using Thermo-Calc Classic (Version S). A detailed description of thermodynamic models and optimization algorithms used to establish the equilibrium compositions of alloys can be found in the Thermo-Calc manual. ${ }^{16}$ A broad exposition of modern thermodynamics behind the Thermo-Calc computational platform is given by Hillert. ${ }^{8}$ In all equilibrium calculations commercial Thermo-Calc databases TTFE6 (iron-based) and TTNI8 (nickel-based) were used. Alloy $800 \mathrm{H}$ contains approximately $46 \mathrm{wt} \%$ iron and $32 \mathrm{wt} \%$ nickel, and the application of either database yielded practically identical results, indicating the robustness of both databases. The calculation of a single equilibrium for Alloy $800 \mathrm{H}$, comprising 12 components and an impurity (sulfur), took no more than 2 to 3 seconds on a PC-based workstation. Calculations for the different isopleths, constructed to probe phase fields and establish the optimal temperature of the diffusion welding process, took from 180 up to 2,000 seconds of CPU time, on average. In addition to thermodynamic and phase field considerations, it is necessary to 
take into account the possibility of creep at elevated temperatures as well as to achieve the relatively large grain size in $800 \mathrm{H}$ necessary to effectively control creep. Only phase diagrams and thermodynamic factors are discussed at this point.

\subsubsection{Diffusion Modeling}

Diffusion modeling was conducted using Dictra Version 25 software-a "sister" program of ThermoCalc that can solve numerous metallurgical problems, as indicated in the Dictra Manual. ${ }^{17}$ It allows the exploration of diffusion-controlled phase transformations, including such phenomena as diffusion couples, both single-phase and heterogeneous. In the latter case, it is assumed that the volume fraction of the second phase (e.g., the $\gamma^{\prime}$ strengthening precipitates or the equilibrium carbide TiC constituent particles in Alloy $800 \mathrm{H}$ ) is small. Additionally, it is assumed that the average concentration in the strengthening phase is defined by the conditions of local equilibrium for the average concentrations of components. ${ }^{17,18}$ Additional explanations and comments to these problems and the methods of their solution can be found in a review by Borgenstam et al. ${ }^{18}$

Given the complexity of the Alloy $800 \mathrm{H}$ system, changes in the titanium-niobium carbonitride ${ }^{b}$ distribution across the welded joint were ignored since the titanium and niobium carbides, nitrides, and carbonitrides are quite stable. These phases form and dissolve only at temperatures near Alloy $800 \mathrm{H}$ 's melting range $\left(>1360^{\circ} \mathrm{C}\right)$, and are thus features of the alloy base metal that are little affected by diffusion welding in the vicinity of $1150^{\circ} \mathrm{C}$. The concentration profiles of the major chemical elements were considered.

The modeled system comprised a $50 \mu \mathrm{m}$ rectangle of Alloy $800 \mathrm{H}$ followed by a $15 \mu \mathrm{m}$ layer of pure nickel filler metal across the diffusion welded joint followed by another $50 \mu \mathrm{m}$ rectangle of $800 \mathrm{H}$. The nickel layer (which may be considered a filler metal) was used because it helped suppress the chromium oxidation process at the faying surface interface, and improved the mating of the welded parts, both of which improve the quality of the welded joint. Nickel plating is an alternative method of applying an interlayer. A nonuniform mesh (option "Double-Geometric" in Dictra) was used with the corresponding factor of 0.98 for both interfaces. This helped introduce more discretized points across the boundaries, where the chemical potential gradients were high, and fewer points far from the weld. The initial concentration of all components, except nickel, which was considered a dependent component, was modeled using two Heaviside functions for each chemical element. For example, in the case of chromium, the following expression was used as the initial condition for diffusion process simulation: $\mathrm{C}_{\mathrm{Cr}}=1.0 \mathrm{e}-6+0.1959 * h s(50 \mathrm{e}-6-\mathrm{x})+0.1959 * h s(\mathrm{x}-65 * \mathrm{e}-6)$. In this expression, 0.1959 is the bulk chromium concentration (weight-fraction) in the Alloy $800 \mathrm{H}$; $1.0 \mathrm{e}-6=10^{-6}$ plays the role of "zero" (a very small number); $15 \mu \mathrm{m}=65 \mu \mathrm{m}-50 \mu \mathrm{m}$ is the width of the nickel interconnect, $x$ stands for the current distance, and " $h s$ " stands for the Heaviside function. To overcome numerical instabilities of integration, a fully-implicit Euler integration method offered in Dictra as an option, was used. A calculation simulating diffusion welding process for 1 hour $\left(3,600\right.$ seconds) at $1150^{\circ} \mathrm{C}$ (the optimal conditions that have been established), took, on average, about 4 hours to complete a simulation run.

\subsection{Results and Discussion}

\subsubsection{Test Matrix}

The scoping test matrix and test completion data is shown in Table 2, which defines the progress of all tests from 1 through 75 .

b. (Ti1-x $\mathrm{Nbx})(\mathrm{C}, \mathrm{N})$, according to the results of equilibrium calculations at $1150^{\circ} \mathrm{C}$. 
Table 2. 800H database scoping study of Table Y11215 (yellow shading denotes completed tests).

\begin{tabular}{|c|c|c|c|c|c|c|c|c|c|c|c|}
\hline \multirow[b]{2}{*}{ Sequence } & \multirow[b]{2}{*}{\begin{tabular}{|c|} 
Specimen \\
(Date Code)
\end{tabular}} & \multicolumn{2}{|c|}{$\begin{array}{l}\text { Surface Condition: } \\
\text { Ground to } 600 \text { Grit }\end{array}$} & \multicolumn{3}{|c|}{ Bonding Geometry } & \multicolumn{3}{|c|}{ Bonding Parameters } & \multirow{2}{*}{$\begin{array}{c}\text { Analysis } \\
\text { UTS } \\
\text { (Mpa if } \\
\text { Tested) } \\
\end{array}$} & \multirow[b]{2}{*}{$\begin{array}{l}\text { He Loop } \\
\text { Exposure }\end{array}$} \\
\hline & & $\begin{array}{l}\text { Ni Plated } \\
\text { (per side) }\end{array}$ & Ni Foil & $\begin{array}{l}\text { Number } \\
\text { of Bonds }\end{array}$ & $\begin{array}{c}\text { Base } \\
\text { Material } \\
\end{array}$ & $\begin{array}{l}\text { Inserted } \\
\text { Material } \\
\end{array}$ & $\begin{array}{c}\text { Time } \\
\text { (hours) }\end{array}$ & $\begin{array}{c}\text { Temp. } \\
\left({ }^{\circ} \mathrm{C}\right)\end{array}$ & $\begin{array}{l}\text { Stress } \\
\text { (MPa) } \\
\end{array}$ & & \\
\hline 1 & X91215 & No & No & 1 & $800 \mathrm{H}$ & - & 2 & 1050 & $2.77 \pm 1.90$ & Met. Mount & - \\
\hline 2 & X91223 & No & No & 1 & $800 \mathrm{H}$ & - & 3 & 1100 & $6.02 \pm 0.34$ & Met. Mount & - \\
\hline 3 & Y00107 & No & No & 1 & $800 \mathrm{H}$ & - & 3 & 1150 & - & Met. Mount & Intended \\
\hline 4 & Y00108 & No & No & 1 & $800 \mathrm{H}$ & - & - & - & - & - & - \\
\hline 5 & Y00111 & $\sim 1 \mu \mathrm{m}$ & No & 1 & $800 \mathrm{H}$ & - & 3 & 1150 & $5.45 \pm 2.91$ & Met. Mount & - \\
\hline 6 & Y00126 & No & $15 \mu \mathrm{m}$ & 1 & $800 \mathrm{H}$ & - & 3 & 1150 & $7.36 \pm 1.24$ & Met. Mount & - \\
\hline 7 & Y00127 & $\sim 1 \mu \mathrm{m}$ & No & 1 & $800 \mathrm{H}$ & 一 & 3 & 1150 & $6.07 \pm 0.61$ & 537.2 & - \\
\hline 8 & Y00128 & No & No & 1 & $800 \mathrm{H}$ & - & 3 & 1150 & $5.72 \pm 1.38$ & 180.0 & - \\
\hline 9 & Y00223 & No & $15 \mu \mathrm{m}$ & 1 & $800 \mathrm{H}$ & - & 3 & 1150 & $6.92 \pm 0.53$ & 526.7 & - \\
\hline 10 & Y00407 & No & No & 1 & $800 \mathrm{H}$ & - & 3 & 1150 & $10.35 \pm 0.54$ & Met. Mount & Run 25 \\
\hline 11 & Y00408A & No & No & 2 & $800 \mathrm{H}$ & Alloy X & 3 & 1150 & $6.22 \pm 0.90$ & Met. Mount & Run 25 \\
\hline 12 & Y00408B & No & $15 \mu \mathrm{m}$ & 2 & $800 \mathrm{H}$ & Alloy X & 3 & 1150 & $4.26 \pm 1.00$ & Met. Mount & Run 25 \\
\hline 13 & Y00414 & No & No & 1 & $800 \mathrm{H}$ & - & 3 & 1150 & $4.38 \pm 0.92$ & 466.0 & - \\
\hline 14 & Y00415A & $\sim 1 \mu \mathrm{m}$ & No & 1 & $800 \mathrm{H}$ & - & 3 & 1150 & $4.72 \pm 1.00$ & 537.0 & - \\
\hline 15 & Y00415B & $\sim 1 \mu \mathrm{m}$ & No & 1 & $800 \mathrm{H}$ & - & 3 & 1150 & $5.08 \pm 0.59$ & 531.0 & - \\
\hline 16 & Y00416 & No & No & 1 & $800 \mathrm{H}$ & - & 3 & 1150 & $4.73 \pm 0.46$ & 536.0 & - \\
\hline 17 & Y00427A & No & No & 1 & $800 \mathrm{H}$ & - & - & - & - & - & - \\
\hline 18 & Y00427B & No & No & 1 & $800 \mathrm{H}$ & - & 3 & 1150 & $5.26 \pm 1.56$ & 187.1 & - \\
\hline 19 & Y00428 & No & $15 \mu \mathrm{m}$ & 1 & $800 \mathrm{H}$ & - & 3 & 1150 & $5.07 \pm 1.61$ & 560.9 & - \\
\hline 20 & Y00511 & No & $15 \mu \mathrm{m}$ & 1 & $800 \mathrm{H}$ & - & 3 & 1150 & $5.45 \pm 1.50$ & 559.2 & - \\
\hline 21 & Y00513 & No & No & 1 & $800 \mathrm{H}$ & - & 3 & 1150 & $4.71 \pm 1.42$ & 333.3 & - \\
\hline 22 & Y00517 & No & No & 3 & $800 \mathrm{H}$ & $800 \mathrm{H}$ & 3 & 1150 & $4.34 \pm 1.34$ & Met. Mount & Intended \\
\hline 23 & Y00520 & No & $15 \mu \mathrm{m}$ & 3 & $800 \mathrm{H}$ & $800 \mathrm{H}$ & 3 & 1150 & $5.15 \pm 0.94$ & Met. Mount & Intended \\
\hline 24 & Y00527 & No & $15 \mu \mathrm{m}$ & 1 & $800 \mathrm{H}$ & - & 1.5 & 1150 & $4.35 \pm 1.05$ & Met. Mount & Intended \\
\hline
\end{tabular}


Table 2. (continued).

\begin{tabular}{|c|c|c|c|c|c|c|c|c|c|c|c|}
\hline \multirow[b]{2}{*}{ Sequence } & \multirow[b]{2}{*}{\begin{tabular}{|c} 
Specimen \\
(Date Code)
\end{tabular}} & \multicolumn{2}{|c|}{$\begin{array}{l}\text { Surface Condition: } \\
\text { Ground to } 600 \text { Grit }\end{array}$} & \multicolumn{3}{|c|}{ Bonding Geometry } & \multicolumn{3}{|c|}{ Bonding Parameters } & \multirow{2}{*}{$\begin{array}{c}\text { Analysis } \\
\text { UTS } \\
\text { (Mpa if } \\
\text { Tested) }\end{array}$} & \multirow[b]{2}{*}{$\begin{array}{l}\text { He Loop } \\
\text { Exposure }\end{array}$} \\
\hline & & $\begin{array}{l}\text { Ni Plated } \\
\text { (per side) }\end{array}$ & Ni Foil & $\begin{array}{l}\text { Number } \\
\text { of Bonds }\end{array}$ & $\begin{array}{c}\text { Base } \\
\text { Material }\end{array}$ & $\begin{array}{l}\text { Inserted } \\
\text { Material } \\
\end{array}$ & $\begin{array}{c}\text { Time } \\
\text { (hours) }\end{array}$ & $\begin{array}{c}\text { Temp. } \\
\left({ }^{\circ} \mathrm{C}\right)\end{array}$ & $\begin{array}{l}\text { Stress } \\
\text { (MPa) }\end{array}$ & & \\
\hline \multicolumn{12}{|c|}{ Future scoping work: Effects of bonding time } \\
\hline 25 & Y00802A & $\sim 1 \mu \mathrm{m}$ & No & 1 & $800 \mathrm{H}$ & - & 1 & 1150 & $6.07 \pm 0.63$ & Met. Mount & Run 31 \\
\hline 26 & Y01118 & $\sim 1 \mu \mathrm{m}$ & No & 1 & $800 \mathrm{H}$ & - & 2 & 1150 & $5.54 \pm 0.73$ & Not Mounted & Intended \\
\hline 27 & Y01213 & $\sim 1 \mu \mathrm{m}$ & No & 1 & $800 \mathrm{H}$ & - & 5 & 1150 & $5.07 \pm 1.57$ & Not Mounted & Intended \\
\hline 28 & Y00803 & $\sim 1 \mu \mathrm{m}$ & No & 1 & $800 \mathrm{H}$ & - & 7 & 1150 & $5.23 \pm 0.99$ & Met. Mount & Run 31 \\
\hline 29 & Y00804A & No & $15 \mu \mathrm{m}$ & 1 & $800 \mathrm{H}$ & - & 1 & 1150 & $5.25 \pm 0.66$ & Met. Mount & Run 31 \\
\hline 30 & Y00804B & No & $15 \mu \mathrm{m}$ & 1 & $800 \mathrm{H}$ & - & 2 & 1150 & $5.27 \pm 1.06$ & Met. Mount & Run 31 \\
\hline 31 & Y01005 & No & $15 \mu \mathrm{m}$ & 1 & $800 \mathrm{H}$ & - & 5 & 1150 & $5.02 \pm 2.10$ & Met. Mount & Run 31 \\
\hline 32 & Y01007 & No & $15 \mu \mathrm{m}$ & 1 & $800 \mathrm{H}$ & - & 7 & 1150 & $4.91 \pm 1.22$ & Not Mounted & Intended \\
\hline 33 & Y00802B & $\sim 1 \mu \mathrm{m}$ & No & 1 & $800 \mathrm{H}$ & - & 1 & 1150 & $5.29 \pm 0.33$ & 532.9 & No \\
\hline 34 & TBD & Yes & No & 1 & $800 \mathrm{H}$ & - & 2 & 1150 & 5 Nom. & Tensile & - \\
\hline 35 & TBD & Yes & No & 1 & $800 \mathrm{H}$ & - & 5 & 1150 & 5 Nom. & Tensile & - \\
\hline 36 & TBD & Yes & No & 1 & $800 \mathrm{H}$ & - & 7 & 1150 & 5 Nom. & Tensile & - \\
\hline 37 & TBD & No & Yes & 1 & $800 \mathrm{H}$ & - & 1 & 1150 & 5 Nom. & Tensile & - \\
\hline 38 & Y01004 & No & $15 \mu \mathrm{m}$ & 1 & $800 \mathrm{H}$ & - & 2 & 1150 & $4.96 \pm 1.29$ & 554.7 & No \\
\hline 39 & Y00812 & No & $15 \mu \mathrm{m}$ & 1 & $800 \mathrm{H}$ & - & 5 & 1150 & 5 Nom. & 536.9 & No \\
\hline 40 & Y01006 & No & $15 \mu \mathrm{m}$ & 1 & $800 \mathrm{H}$ & - & 7 & 1150 & 5 Nom. & Not Tested & - \\
\hline 41 & TBD & Yes & No & 1 & $800 \mathrm{H}$ & - & 1 & 1150 & 5 Nom. & Tensile & - \\
\hline 42 & TBD & Yes & No & 1 & $800 \mathrm{H}$ & - & 2 & 1150 & 5 Nom. & Tensile & - \\
\hline 43 & TBD & Yes & No & 1 & $800 \mathrm{H}$ & - & 5 & 1150 & 5 Nom. & Tensile & - \\
\hline 44 & TBD & Yes & No & 1 & $800 \mathrm{H}$ & - & 7 & 1150 & 5 Nom. & Tensile & - \\
\hline 45 & TBD & No & Yes & 1 & $800 \mathrm{H}$ & - & 1 & 1150 & 5 Nom. & Tensile & - \\
\hline 46 & TBD & No & Yes & 1 & $800 \mathrm{H}$ & - & 2 & 1150 & 5 Nom. & Tensile & - \\
\hline 47 & TBD & No & Yes & 1 & $800 \mathrm{H}$ & - & 5 & 1150 & 5 Nom. & Tensile & - \\
\hline 48 & TBD & No & Yes & 1 & $800 \mathrm{H}$ & - & 7 & 1150 & 5 Nom. & Tensile & - \\
\hline
\end{tabular}


Table 2. (continued).

\begin{tabular}{|c|c|c|c|c|c|c|c|c|c|c|c|}
\hline \multirow[b]{2}{*}{ Sequence } & \multirow[b]{2}{*}{$\begin{array}{c}\text { Specimen } \\
\text { (Date Code) }\end{array}$} & \multicolumn{2}{|c|}{$\begin{array}{l}\text { Surface Condition: } \\
\text { Ground to } 600 \text { Grit }\end{array}$} & \multicolumn{3}{|c|}{ Bonding Geometry } & \multicolumn{3}{|c|}{ Bonding Parameters } & \multirow{2}{*}{$\begin{array}{c}\text { Analysis } \\
\text { UTS } \\
\text { (Mpa if } \\
\text { Tested) }\end{array}$} & \multirow[b]{2}{*}{$\begin{array}{r}\text { He Loop } \\
\text { Exposure }\end{array}$} \\
\hline & & $\begin{array}{l}\text { Ni Plated } \\
\text { (per side) }\end{array}$ & Ni Foil & $\begin{array}{l}\text { Number } \\
\text { of Bonds }\end{array}$ & $\begin{array}{c}\text { Base } \\
\text { Material }\end{array}$ & $\begin{array}{l}\text { Inserted } \\
\text { Material }\end{array}$ & \begin{tabular}{|c} 
Time \\
(hours)
\end{tabular} & $\begin{array}{l}\text { Temp. } \\
\left({ }^{\circ} \mathrm{C}\right)\end{array}$ & $\begin{array}{l}\text { Stress } \\
(\mathrm{MPa})\end{array}$ & & \\
\hline \multicolumn{12}{|c|}{ Effects of multiple layers, similar to printed circuit heat exchanger geometry } \\
\hline 49 & TBD & Yes & No & 2 & $800 \mathrm{H}$ & $800 \mathrm{H}$ & 3 & 1150 & 5 Nom. & Met. Mount & Intended \\
\hline 50 & TBD & Yes & No & 2 & $800 \mathrm{H}$ & $800 \mathrm{H}$ & 3 & 1150 & 5 Nom. & Tensile & - \\
\hline 51 & TBD & Yes & No & 2 & $800 \mathrm{H}$ & $800 \mathrm{H}$ & 3 & 1150 & 5 Nom. & Tensile & - \\
\hline 52 & TBD & Yes & No & 3 & $800 \mathrm{H}$ & $800 \mathrm{H}$ & 3 & 1150 & 5 Nom. & Met. Mount & Intended \\
\hline 53 & TBD & Yes & No & 3 & $800 \mathrm{H}$ & $800 \mathrm{H}$ & 3 & 1150 & 5 Nom. & Tensile & - \\
\hline 54 & TBD & Yes & No & 3 & $800 \mathrm{H}$ & $800 \mathrm{H}$ & 3 & 1150 & 5 Nom. & Tensile & - \\
\hline 55 & TBD & No & Yes & 2 & $800 \mathrm{H}$ & $800 \mathrm{H}$ & 3 & 1150 & 5 Nom. & Met. Mount & Intended \\
\hline 56 & TBD & No & Yes & 2 & $800 \mathrm{H}$ & $800 \mathrm{H}$ & 3 & 1150 & 5 Nom. & Tensile & - \\
\hline 57 & TBD & No & Yes & 2 & $800 \mathrm{H}$ & $800 \mathrm{H}$ & 3 & 1150 & 5 Nom. & Tensile & - \\
\hline 58 & TBD & No & Yes & 3 & $800 \mathrm{H}$ & $800 \mathrm{H}$ & 3 & 1150 & 5 Nom. & Met. Mount & Intended \\
\hline 59 & TBD & No & Yes & 3 & $800 \mathrm{H}$ & $800 \mathrm{H}$ & 3 & 1150 & 5 Nom. & Tensile & - \\
\hline 60 & TBD & No & Yes & 3 & $800 \mathrm{H}$ & $800 \mathrm{H}$ & 3 & 1150 & 5 Nom. & Tensile & - \\
\hline \multicolumn{12}{|c|}{ Use of larger diameter materials } \\
\hline 61 & TBD & Yes & No & 2 & $800 \mathrm{H}$ & $800 \mathrm{H}$ & 3 & 1150 & 5 Nom. & Met. Mount & Intended \\
\hline 62 & TBD & Yes & No & 2 & $800 \mathrm{H}$ & $800 \mathrm{H}$ & 3 & 1150 & 5 Nom. & Tensile & - \\
\hline 63 & TBD & Yes & No & 2 & $800 \mathrm{H}$ & $800 \mathrm{H}$ & 3 & 1150 & 5 Nom. & Tensile & - \\
\hline 64 & TBD & Yes & No & 3 & $800 \mathrm{H}$ & $800 \mathrm{H}$ & 3 & 1150 & 5 Nom. & Met. Mount & Intended \\
\hline 65 & TBD & Yes & No & 3 & $800 \mathrm{H}$ & $800 \mathrm{H}$ & 3 & 1150 & 5 Nom. & Tensile & - \\
\hline 66 & TBD & Yes & No & 3 & $800 \mathrm{H}$ & $800 \mathrm{H}$ & 3 & 1150 & 5 Nom. & Tensile & - \\
\hline 67 & Y01027 & No & $15 \mu \mathrm{m}$ & 1 & $800 \mathrm{H}$ & 1.0 inch & 3 & 1150 & $4.51 \pm 0.51$ & Met. Mount & Intended \\
\hline 68 & TBD & No & Yes & 2 & $800 \mathrm{H}$ & $800 \mathrm{H}$ & 3 & 1150 & 5 Nom. & Tensile & - \\
\hline 69 & TBD & No & Yes & 2 & $800 \mathrm{H}$ & $800 \mathrm{H}$ & 3 & 1150 & 5 Nom. & Tensile & - \\
\hline 70 & Y01029 & No & $5 \mu \mathrm{m}$ & 1 & $800 \mathrm{H}$ & 0.75 inch & 3 & 1150 & $5.07 \pm 0.40$ & Not Mounted & Intended \\
\hline 71 & TBD & No & Yes & 3 & $800 \mathrm{H}$ & $800 \mathrm{H}$ & 3 & 1150 & 5 Nom. & Tensile & - \\
\hline 72 & TBD & No & Yes & 3 & $800 \mathrm{H}$ & $800 \mathrm{H}$ & 3 & 1150 & 5 Nom. & Tensile & - \\
\hline
\end{tabular}


Table 2. (continued).

\begin{tabular}{|c|c|c|c|c|c|c|c|c|c|c|c|}
\hline \multirow[b]{2}{*}{ Sequence } & \multirow[b]{2}{*}{$\begin{array}{c}\text { Specimen } \\
\text { (Date Code) }\end{array}$} & \multicolumn{2}{|c|}{$\begin{array}{l}\text { Surface Condition: } \\
\text { Ground to } 600 \text { Grit }\end{array}$} & \multicolumn{3}{|c|}{ Bonding Geometry } & \multicolumn{3}{|c|}{ Bonding Parameters } & \multirow{2}{*}{$\begin{array}{c}\text { Analysis } \\
\text { UTS } \\
\text { (Mpa if } \\
\text { Tested) }\end{array}$} & \multirow[b]{2}{*}{$\begin{array}{l}\text { He Loop } \\
\text { Exposure }\end{array}$} \\
\hline & & \begin{tabular}{|l|} 
Ni Plated \\
(per side)
\end{tabular} & Ni Foil & $\begin{array}{l}\text { Number } \\
\text { of Bonds }\end{array}$ & $\begin{array}{c}\text { Base } \\
\text { Material }\end{array}$ & $\begin{array}{l}\text { Inserted } \\
\text { Material }\end{array}$ & \begin{tabular}{|c} 
Time \\
(hours)
\end{tabular} & $\begin{array}{l}\text { Temp. } \\
\left({ }^{\circ} \mathrm{C}\right)\end{array}$ & $\begin{array}{l}\text { Stress } \\
(\mathrm{MPa})\end{array}$ & & \\
\hline \multicolumn{12}{|c|}{ Miscellaneous tests in addition to original matrix } \\
\hline 73 & Y00720A & $\sim 1 \mu \mathrm{m}$ & No & 1 & $800 \mathrm{H}$ & - & 1.5 & 1150 & $5.25 \pm 0.92$ & 548.5 & No \\
\hline 74 & Y00720B & $\sim 1 \mu \mathrm{m}$ & No & 1 & $800 \mathrm{H}$ & - & 1.5 & 1150 & $5.02 \pm 0.57$ & 549.5 & No \\
\hline 75 & Y10113 & $\sim 1 \mu \mathrm{m}$ & No & 1 & $800 \mathrm{H}$ & - & 3 & 1150 & $5.02 \pm 0.58$ & Not Tested & - \\
\hline
\end{tabular}


The nominal welding parameters for these tests were a temperature of $1150^{\circ} \mathrm{C}, 5 \mathrm{MPa}$ applied stress, and 3 -hour hold time under a vacuum of about $5 \times 10^{-4}$ Torr. As will be discussed later, the thermodynamic and kinetic modeling effort suggested that a time of 1-hour at these same parameters would be sufficient. Although the 3-hour time proved to be effective, the modeling indicated that shorter times, on the order of 1-hour, might also be sufficient. This would have an advantage in reducing overall creep and in productivity. It might also be that a relatively short time under compressive load followed by a much longer time at elevated temperature (i.e., a post-weld heat treatment) would be beneficial.

\subsubsection{Mechanical Properties}

Figure 3 shows (1) the as-tested tensile bars of an alloy bar in the as-received condition along with diffusion welded samples of alloy $800 \mathrm{H}$ prepared with the following bond interface preparation: (2) nickel electroplate $1 \mu \mathrm{m}$ thick on each mating surface, (3) interface of $15 \mu \mathrm{m}$ nickel foil placed between 600 grit ground mating surfaces, and (4) mating surfaces ground to a 600 grit finish, As can be seen in Figure 4, the ultimate tensile strength of bonds using filler metal (nickel plate or foil) is typically near that of the base metal. The only specimens showing reduced strengths are those made with ground surfaces that had no added filler metal.

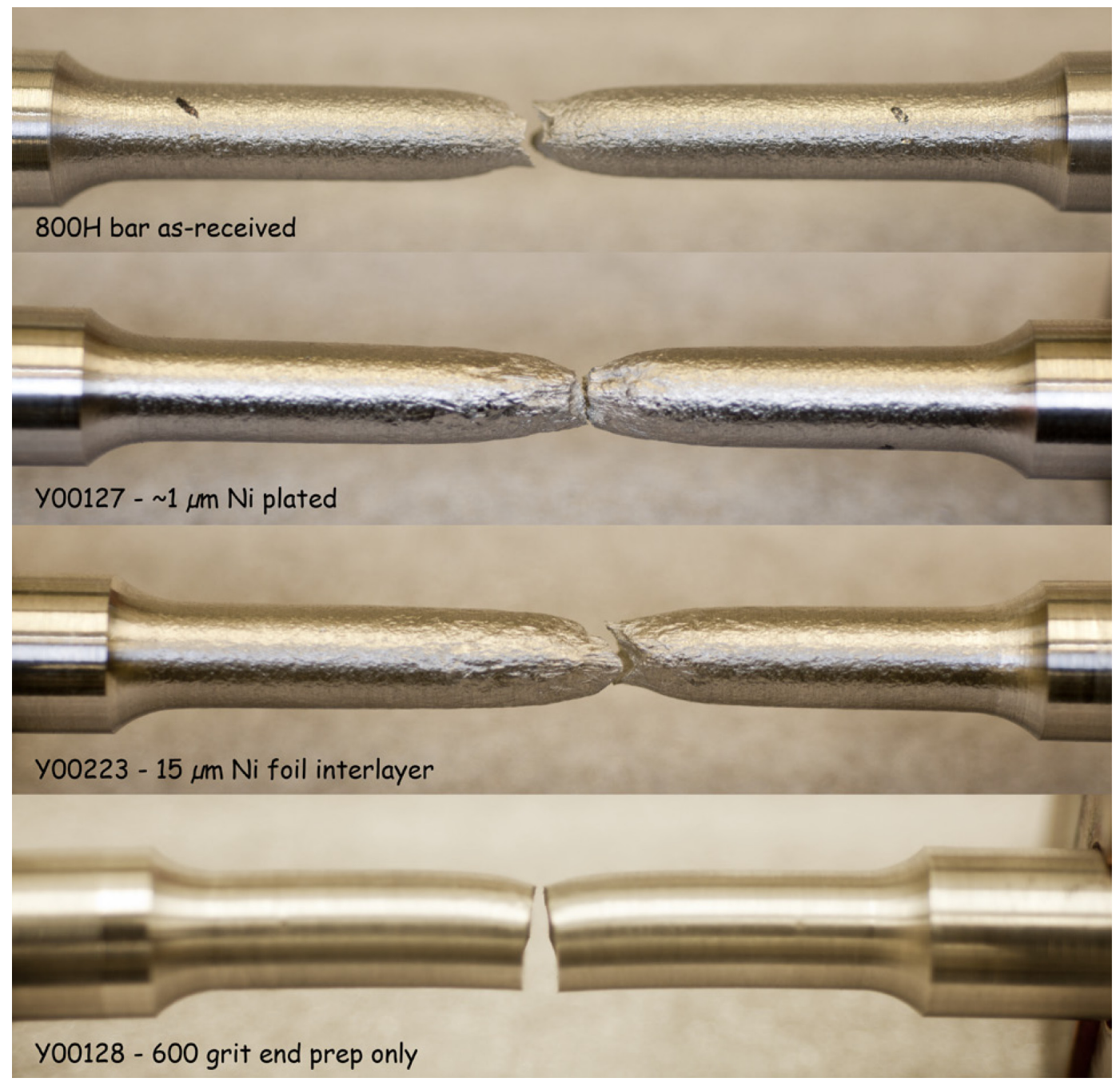

Figure 3. Tensile test specimens. 


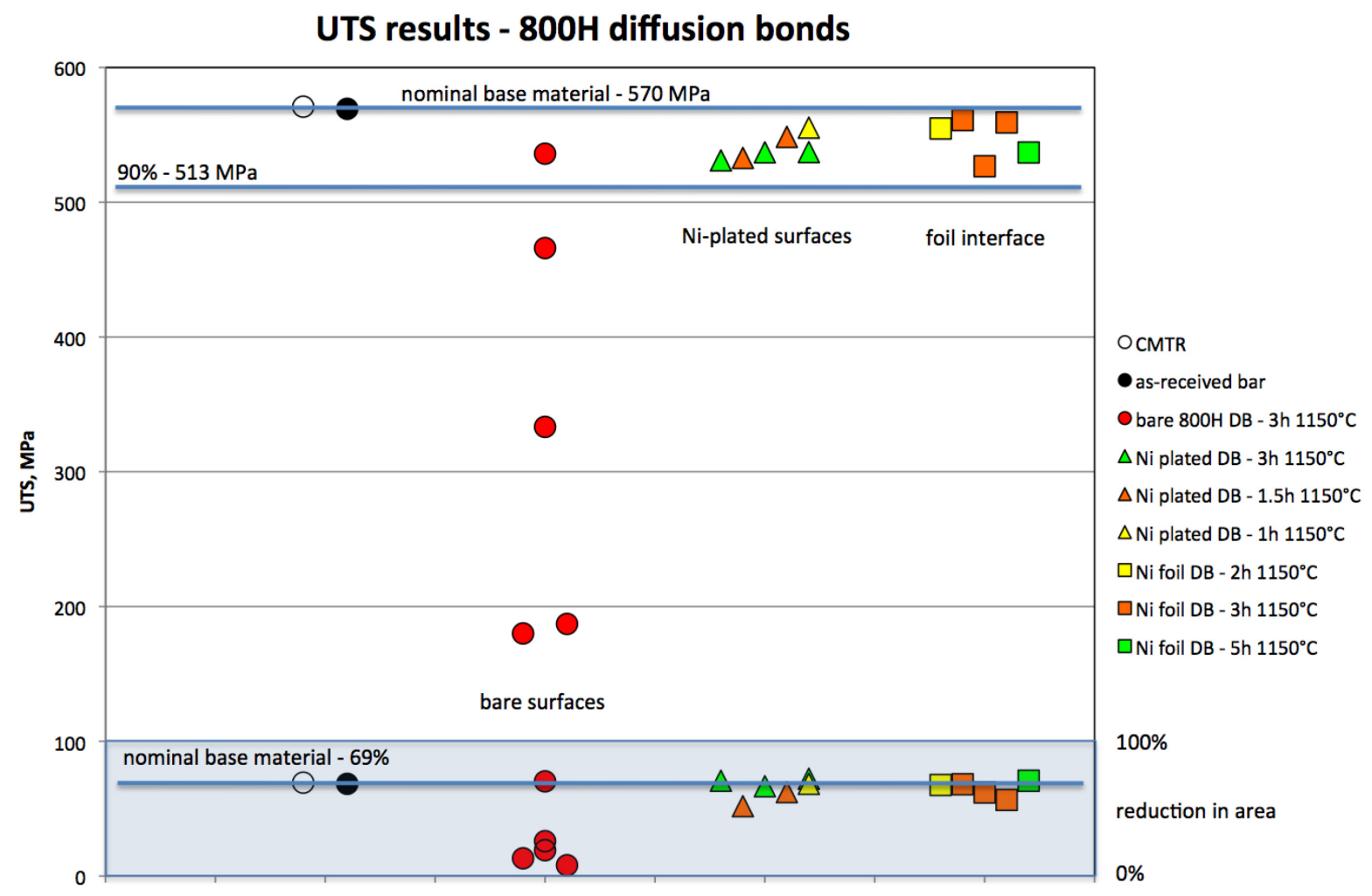

Figure 4. Ultimate tensile strength results.

Various diffusion welded alloy $800 \mathrm{H}$ specimens were tensile tested per the requirements of ASTM International $\mathrm{E} 8{ }^{13}$ with the results shown in Table 3 and plotted in Figure 4. As-received specimens were machined out of the 0.5 in. round bar. All samples were ground though a 600 or 800 grit surface finish on the bonding (faying) surfaces. Added filler metal of pure nickel were also investigated. Some samples had an electrodeposited nickel layer of about $1 \mu \mathrm{m}$ on both bonding surfaces. Other welds used a $15 \mu \mathrm{m}$ thick nickel foil placed between the 600 grit finished surfaces. The optimized welding parameters were found to be $1150^{\circ} \mathrm{C}$ for 3 hours, with approximately $5 \mathrm{MPa}$ of applied compressive stress. This was based on metallographic examination of the initial welds and on the experience of previous diffusion bonding of Alloy 617. Earlier work (not shown here), using lower temperatures and times, produced insufficient bonding in the specimens examined by metallography. Stresses of 3 to $5 \mathrm{MPa}$ were chosen also based on Alloy 617 experience and observations that a stress of $10 \mathrm{MPa}$ causes macroscale creep deformation.

The ultimate tensile strength of specimens fabricated with either nickel-plating or a nickel interlayer is typically near that of the base metal. The specimens showing reduced strengths were made with ground surfaces (no nickel plating or nickel interlayer). This reduced strength may be caused by alignment problems with some of the specimens. These specimens fractured at the bond line with evidence of heat tinting, indicating that the specimen was heated while the interface was not bonding in those areas, and residual gases in the vacuum chamber were able to oxidize the surface. The one specimen without a filler metal addition that exhibited good properties was given an overnight pump-down in the Gleeble System vacuum chamber. This measurement should be repeated in additional testing. Ni foil or Ni plating can increase part conformance and protect from oxidation during heating; ground faying surfaces might not conform where pressures are low to avoid creep at the bonding temperature. 
Table 3. Mechanical properties data.

\begin{tabular}{|c|c|c|c|c|c|c|c|}
\hline Sample & Interface & $\begin{array}{c}\text { Time } \\
\text { (hours) }\end{array}$ & $\begin{array}{l}\text { Temp. } \\
\left({ }^{\circ} \mathrm{C}\right)\end{array}$ & $\begin{array}{c}\text { Bond } \\
\text { Stress } \\
\text { (MPa) } \\
\end{array}$ & $\begin{array}{c}\text { YS } \\
(\mathrm{MPa})\end{array}$ & $\begin{array}{c}\text { UTS } \\
(\mathrm{MPa})\end{array}$ & $\begin{array}{l}\text { RA } \\
(\%)\end{array}$ \\
\hline $\begin{array}{l}\text { 800H-SMC } \\
\text { (CMTR* data) }\end{array}$ & - & - & - & - & 238.6 & 570.9 & 69.3 \\
\hline $\begin{array}{l}\text { 800H-AR } \\
\text { (INL analysis) }\end{array}$ & - & - & - & - & 220.0 & 569.3 & 64.4 \\
\hline Y00126 & Ground, 600 grit, $15 \mu \mathrm{m} \mathrm{Ni}$ foil & 3 & 1150 & 7.00 & - & - & - \\
\hline Y00127 & $\begin{array}{l}\text { Ground, } 600 \text { grit, Ni plated } \sim 1 \\
\mu \mathrm{m} \text { on each surface }\end{array}$ & 3 & 1150 & 6.04 & 178.0 & 537.2 & 69.7 \\
\hline Y00128 & Ground, 600 grit & 3 & 1150 & 5.93 & $<180$ & 180.0 & 12.9 \\
\hline Y00223 & Ground, 600 grit, $15 \mu \mathrm{m}$ Ni foil & 3 & 1150 & 6.00 & 178.0 & 526.7 & 62.3 \\
\hline Y00414 & Ground, 800 grit & 3 & 1150 & 4.38 & - & 466 & 25.9 \\
\hline Y00415A & Ground, 600 grit, Ni-plate & 3 & 1150 & 4.72 & - & 537 & 66.6 \\
\hline Y00415B & Ground, 600 grit, Ni-plate & 3 & 1150 & 5.08 & - & 531.0 & 70.7 \\
\hline Y00416 & $\begin{array}{l}\text { Ground, } 800 \text { grit, overnight } \\
\text { vacuum }\end{array}$ & 3 & 1150 & 4.73 & - & 536 & 70.3 \\
\hline Y00427B & Ground, 800 grit & 3 & 1150 & 5.26 & - & 187.1 & 8.0 \\
\hline Y00428 & Ground, 800 grit, $15 \mu \mathrm{Ni}$ foil & 3 & 1150 & & - & 560.9 & 68.1 \\
\hline Y00511 & Ground, 800 grit, $15 \mu$ Ni foil & 3 & 1150 & 5.45 & - & 559.2 & 56.5 \\
\hline Y00513 & Ground, 800 grit & 3 & 1150 & 4.71 & - & 333.3 & 19.2 \\
\hline Y00720A & Ground, 600 grit, Ni plate & 1.5 & 1150 & 5.25 & - & 548.5 & 62.3 \\
\hline Y00720B & Ground, 600 grit, Ni plate & 1.5 & 1150 & 5.02 & - & 549.5 & 51.8 \\
\hline Y00802B & Ground, 600 grit, Ni plate & 1 & 1150 & 5.29 & - & 539.2 & 68.4 \\
\hline Y00812 & Ground, 600 grit, $15 \mu$ Ni foil & 5 & 1150 & 5 (nom) & - & 536.9 & 70.7 \\
\hline Y01004 & Ground, 600 grit, $15 \mu \mathrm{Ni}$ foil & 2 & 1150 & 4.96 & - & 554.7 & 67.6 \\
\hline
\end{tabular}

\subsubsection{Thermodynamic Modeling using Thermo-Calc ${ }^{\odot}$}

Before conducting any diffusion welding modeling, it was important to establish the equilibrium phase composition of Alloy $800 \mathrm{H}$ at all temperatures of interest, notably $1150^{\circ} \mathrm{C}$. Indeed, higher temperatures will result in accelerated creep and creep-rupture of the samples, while at lower temperatures it would take too much time for thermally activated diffusion processes to proceed. Consequently, the temperature optimization hold point had to be determined based upon these factors, and an understanding of the appearance of other possible phases in the $800 \mathrm{H}$ microstructure incorporated as a function of temperature.

It is important to emphasize that this is not a systematic thermodynamic study of the complex 12-component plus 1 impurity system representing Alloy $800 \mathrm{H}$. Rather, the goal was to understand the alloy's phase composition as a function of temperature and the concentrations of its different components and, on that basis, to optimize the subsequent diffusion welding process. To achieve that goal, changes in the phase composition of Alloy $800 \mathrm{H}$ were plotted as a function of temperature, as shown in Figure 5. 


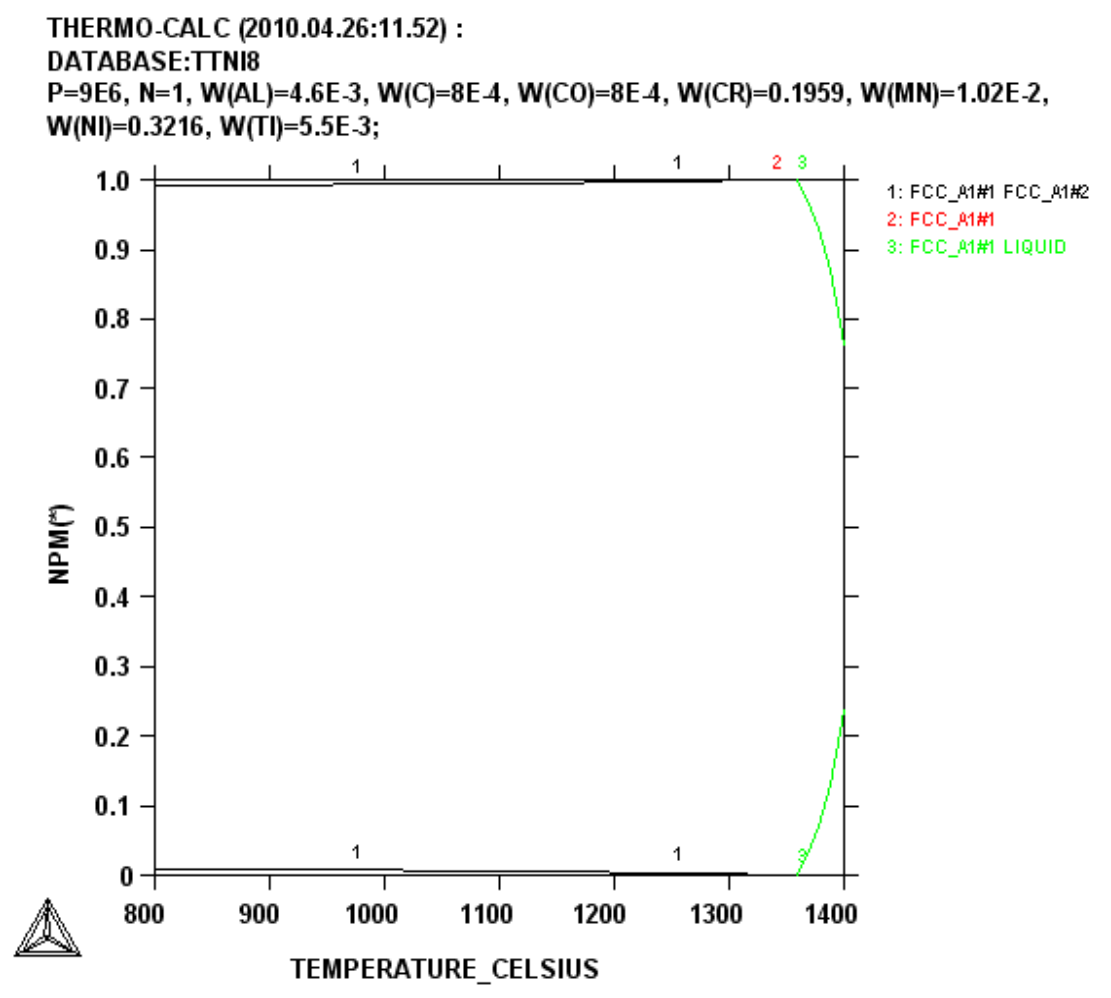

Figure 5. Phase composition of Alloys $800 \mathrm{H}$ as a function of temperature.

This "phase composition - temperature" property diagram demonstrates that in a temperature range from $800^{\circ} \mathrm{C}$ up to $\sim 1320^{\circ} \mathrm{C}$, the microstructure of Alloy $800 \mathrm{H}$ is defined by the austenitic matrix and a relatively small amount of the mixed titanium and niobium carbonitrides. These are constituent particles that disappear only at temperatures above $\sim 1320^{\circ} \mathrm{C}$, followed by melting of the Alloy $800 \mathrm{H}$ beginning at $\sim 1360^{\circ} \mathrm{C}$. Within this broad temperature range, from $800^{\circ} \mathrm{C}$ to $\sim 1300^{\circ} \mathrm{C}$, the volume fraction of the $[(\mathrm{Ti}$, $\mathrm{Nb})(\mathrm{C}, \mathrm{N})$ ] particles remains small (less than $0.5 \%$ ). It follows from a single equilibrium calculation at $1150^{\circ} \mathrm{C}$ that the concentration of niobium in these constituents was $\sim 10$ times higher than in the fcc matrix, and nitrogen is higher by 4 orders of magnitude in the fcc matrix.

The chemical composition of the several carbonitride particles established using energy-dispersive $\mathrm{x}$ ray spectroscopy (EDX). Imaging of these secondary phases with the SEM is shown in Figure 6 . The particles present in microstructure, in agreement with thermodynamic calculations, are [(Ti, Nb) $(\mathrm{C}, \mathrm{N})]$. Chemical compositions of the particles, according to the results of EDX analyses, are as follows (all in at \%): Particle 1: C-30.3; N-12.6; Ti-40.4; Nb-5.7; Fe-4.6; Cr-2.9; Ni-2.8; Mo-1.25. Particle 2: C-36.5; Ti-42.4; Nb-11.7; Fe-3.2; Cr-2.7; Ni-1.7; and Mo-1.7.

The presence of $0.053 \mathrm{wt} \%$ niobium and $0.007 \mathrm{wt} \%$ nitrogen in Alloy $800 \mathrm{H}$ samples was something of a surprise, as these elements are not listed in the ASTM International specification for this alloy. However, because superalloys are often recycled, one should expect that small amounts of such tramp elements could nevertheless be present. Such impurities are typical of real alloys and can be a complicating factor in accurate modeling.

All subsequent thermodynamic calculations were made under the assumption that the niobium concentration in the studied alloy was zero. This was done to expedite thermodynamic calculations and also to make the modeled diagrams less overburdened with different phase domains. The concentration of nitrogen was taken as measured and reported in Table 1 as $0.07 \mathrm{wt} \%$. 


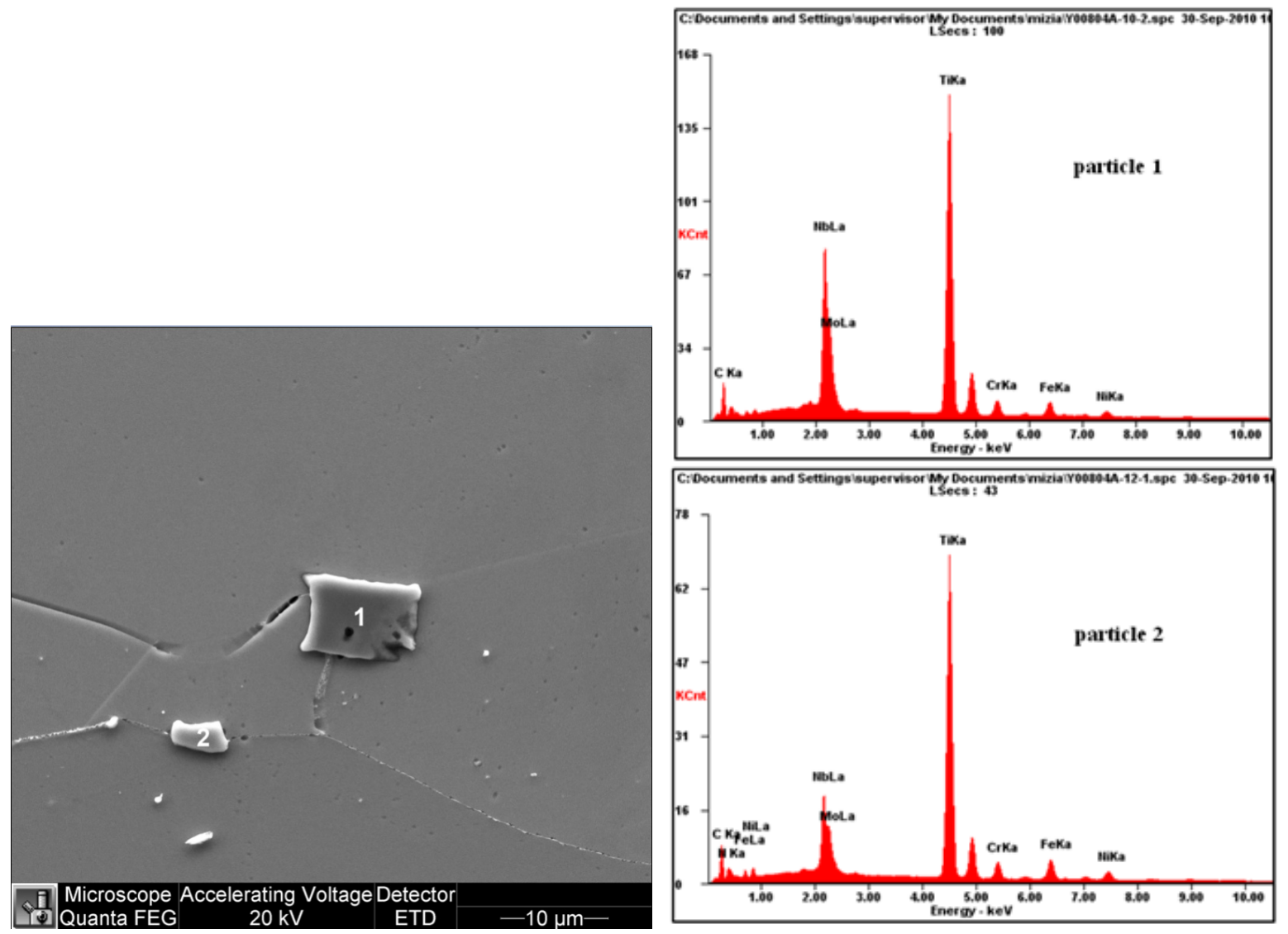

Figure 6. SEM image of an Alloy $800 \mathrm{H}$ sample heat treated at $1150^{\circ} \mathrm{C}$ for 3 hours and then quenched to room temperature.

The introduction of niobium into the computations at temperatures above $800^{\circ} \mathrm{C}$ results in the formation of a mixed compound $[(\mathrm{Ti}, \mathrm{Nb})(\mathrm{C}, \mathrm{N})]$, with practically all niobium entering the composition of these constitutive particles (see above). As temperature decreases, the $\mathrm{D}_{22}$-superstructure $\left(\mathrm{Ni}_{3} \mathrm{Nb}\right)$ can be formed in addition to the $\mathrm{L}_{2}$ superstructure $\left(\mathrm{Ni}_{3} \mathrm{Ti}\right)^{\mathrm{c}}$. In the literature, ${ }^{2}$ these compounds are called the $\gamma$ ' - and the $\gamma^{\prime}$-phases, respectively. The locations of phase equilibrium boundaries (e.g., the precipitation of $\mathrm{M}_{23} \mathrm{C}_{7}$ ) can also be shifted in the "temperature - concentration" figurative space of the diagram.

Among other phases found in Alloy $800 \mathrm{H}$, it is important to mention the sulfur-bearing particles that were observed. ${ }^{19}$ For this reason sulfur was included in thermodynamic calculations, even though this impurity's concentration in $800 \mathrm{H}$ was very small, $0.001 \mathrm{wt} \%$ sulfur. As it follows from the carbon isopleth analysis shown in Figure 7, it was indeed established that such compounds as manganese sulfide, titanium carbosulfide, $\mathrm{Ti}_{4} \mathrm{C}_{2} \mathrm{~S}_{2}$, and pyrrhotite (containing titanium, manganese, sulfur, and other elements) could be found in $800 \mathrm{H}$, in agreement with experimental results. ${ }^{19}$

There have been numerous research efforts aimed at the microstructural characterization of Alloy $800 \mathrm{H}$ under different heat treatment conditions, ${ }^{20,21}$ so the general understanding of the alloy microstructure problem achieved during the last 30 years is very good. However, the thermodynamics modeling work for such complex materials that would reconcile and explain the phase equilibria and thermodynamic data is practically absent. This was yet another rationale for undertaking the present work.

c. Structurbericht designation $L 12$ corresponds to the Pearson symbol cP4 with prototype Cu3Au; while the D022 designation - to the Pearson symbol tI8 with prototype TiGa3. 


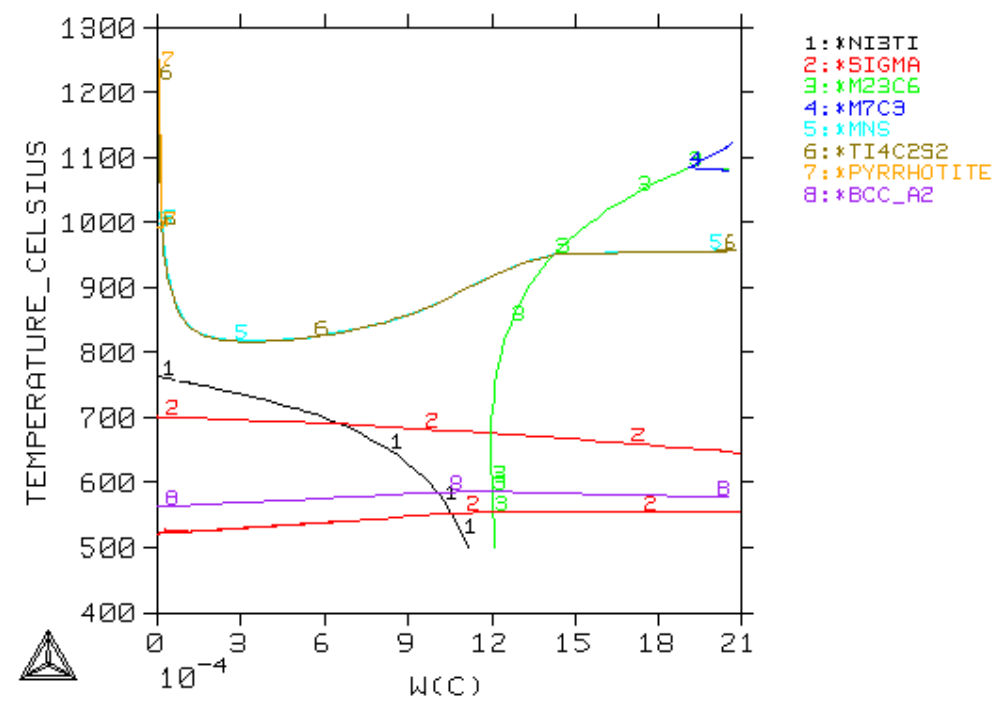

Figure 7. Carbon-isopleth for Alloy $800 \mathrm{H}$.

An interesting feature of the carbon isopleth in Figure 7 is the appearance of the sigma phase (a bcc intermetallic compound containing iron and chromium). The red lines correspond to the appearance and disappearance of the sigma phase. As can be seen, the two elements can be in equilibrium with a bcc phase representing solid solutions of chromium in iron. To better understand the nature of these equilibria, the binary iron-chromium phase diagram was reviewed and is shown as Figure 8. It was calculated using the software and databases indicated above.

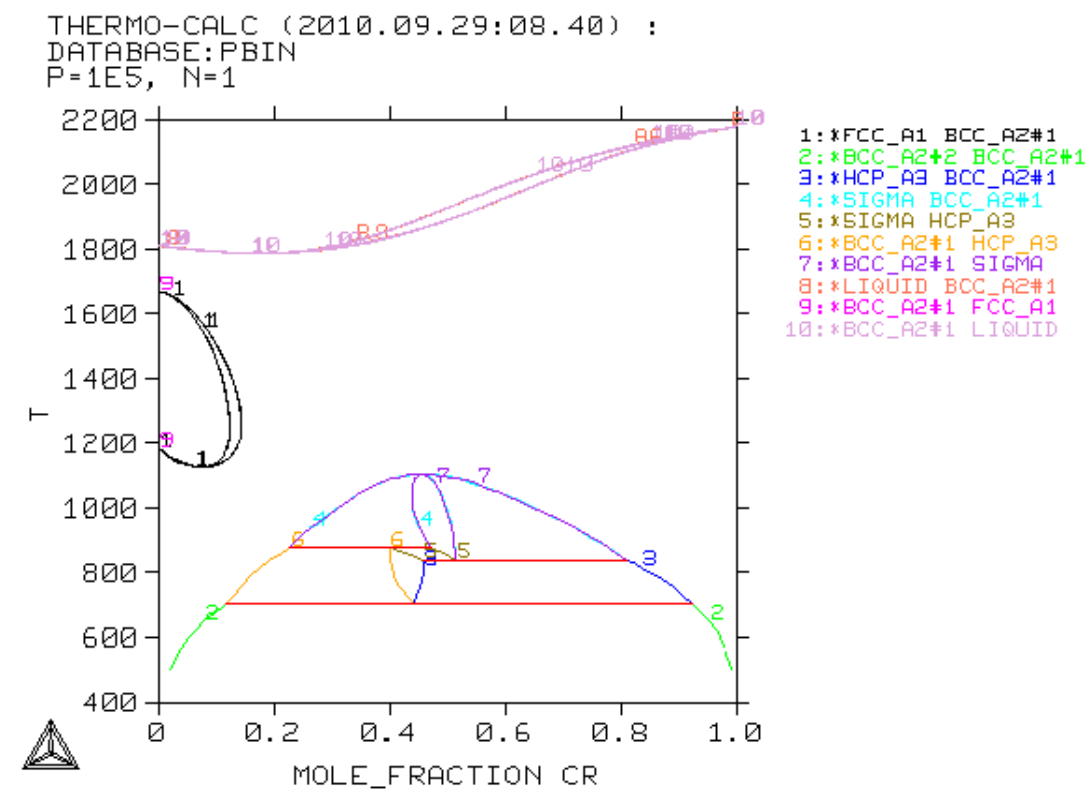

Figure 8. Chromium-isopleth for Alloy $800 \mathrm{H}$.

The chromium-isopleth diagram in Figure 8 is characterized by miscibility gap in the solid state. The sigma phase can be in equilibrium with iron-chromium and chromium-iron solid solutions, lines 7 and 4 . This suggests that the appearance of the bcc phase on the diagram was related to the miscibility gap. This assumption was checked by constructing the chromium-isopleth shown in Figure 9. 


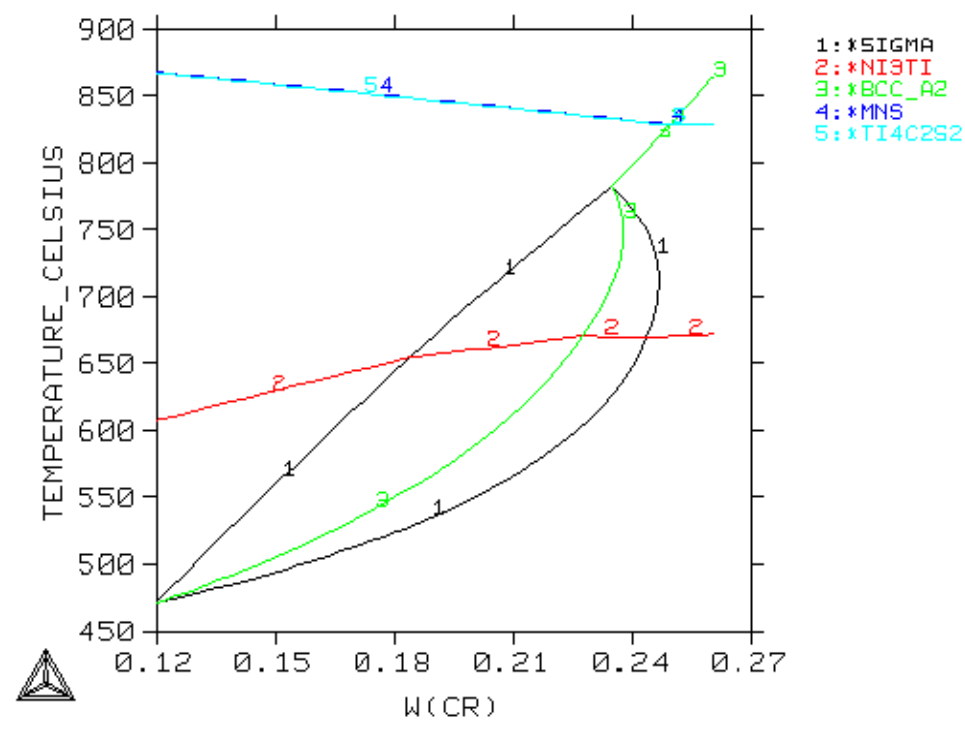

Figure 9. Chromium-isopleth for Alloy $800 \mathrm{H}$.

It is obvious in Figure 9 that all three branches corresponding to the sigma phase at $\sim 770^{\circ} \mathrm{C}$, which below the miscibility gap coalesce into a single phase again at $\sim 475^{\circ} \mathrm{C}$. Consequently, according to the model, the potential appearance of a small amount of bcc chromium-iron solid solution in the fcc matrix accompanying the formation of the sigma phase is to be expected.

Overall, the relatively narrow temperature range from $\sim 800^{\circ} \mathrm{C}$ down to $450^{\circ} \mathrm{C}$ should be treated with extreme caution, as a number of different phases may precipitate from the austenite fcc-solid solution matrix when exposed to this temperature range for a sufficient time. In particular, this information needs to be taken into account when evaluating welding regimes for Alloy $800 \mathrm{H}$ and similar materials, e.g., cooling diffusion-welded samples from $1150^{\circ} \mathrm{C}$ to ambient temperature. Although the Gleeble is capable of relatively rapid cooling through this range, processes commonly used for the fabrication of actual components may not be able to achieve this. Phases formed in this lower temperature regime may also be an issue in service.

The titanium-isopleth for Alloy $800 \mathrm{H}$ is shown in Figure 10. 


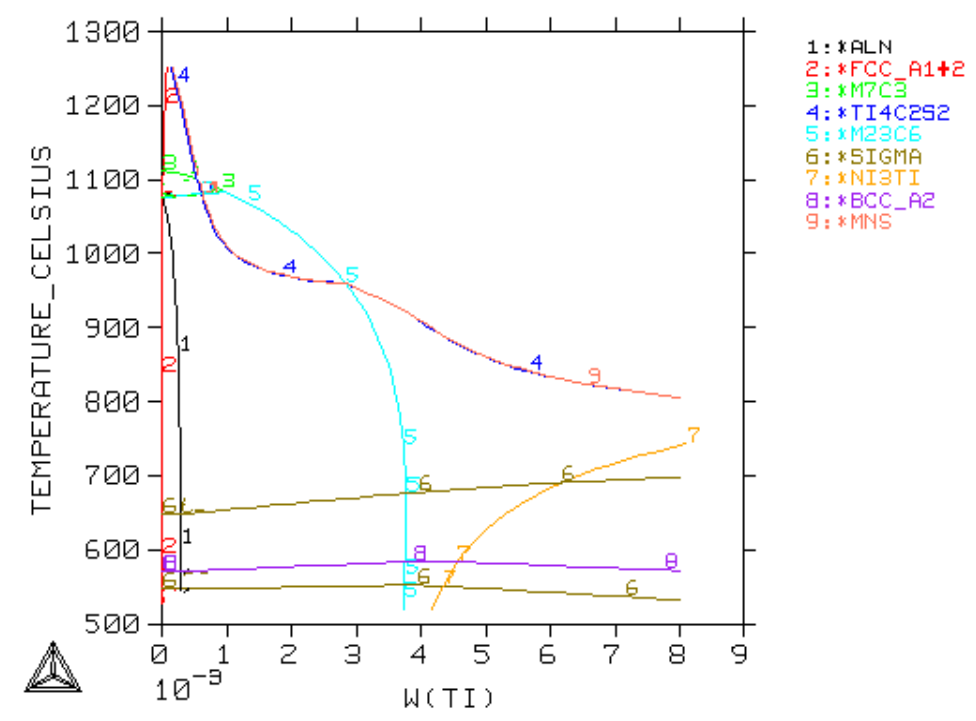

Figure 10. Titanium-isopleth for Alloy $800 \mathrm{H}$.

The titanium-isopleth shown in Figure 10 demonstrates convincingly that, for the selected concentrations of nickel and titanium-32.16 and $0.46 \mathrm{wt} \%$, respectively - as well as other chemical elements in $800 \mathrm{H}$, the phase field comprising the fcc matrix and [(Ti,Nb)(C,N)] constituents exists in a very broad range of temperatures; the same range that was established from the property "step" diagram in Figure 5.

Again, the principal thrust of this work was not aimed at studying complex phase equilibria in 12-component superalloys, but rather, to get useful information for the simulation of the diffusion welding process of components made of such alloys. This work, both experimental and modeling, is described below.

\subsubsection{Dictra Modeling of the $800 \mathrm{H} / \mathrm{Ni} / 800 \mathrm{H}$ Diffusion Couple, Comparison to Experiment, and Optimization of Welding Conditions}

Dictra is a versatile tool for studying practically all of the diffusion controlled phenomena in metallurgical systems. In particular, diffusion couples of different types (I, II, or III, according to the classification proposed by Morral, Jin, Engstrom, and Agren ${ }^{22}$ and Hopfe and Morral ${ }^{23,21}$ ) may undergo a cascade of phase transformations at the interface while reducing the chemical potential gradient of the system and approaching equilibrium. The present work is limited to the construction of concentration profiles for the principal alloying elements in the Alloy $800 \mathrm{H}$ specification (iron, chromium, and nickel) in contact with nickel. In order to accelerate the already slow process of computing diffusion processes in an 11-component Alloy $800 \mathrm{H}$, it was decided at the first stage to ignore the evolution of the $[(\mathrm{Ti}, \mathrm{Nb})(\mathrm{C}$, $\mathrm{N})$ ] constituent particles' spatial distribution.

The concentration profiles modeled using the techniques described in Section 2 are presented in Figure 11. It can be seen that in the case of the three major elements in Alloy $800 \mathrm{H}$ (chromium, iron, and nickel) that there is a reasonable degree of agreement between the results of calculations and experimentally measured (EDS) concentration profiles. Similar results were obtained for all other chemical elements. This suggests that the original assumptions (ignoring $[(\mathrm{Tl}, \mathrm{Nb})(\mathrm{C}, \mathrm{N})]$-constituents) were reasonable, and the quality of the thermodynamic and mobility data bases used was adequate.

The quantitative agreement between the results of modeling and experiment is not complete. Indeed, all modeling results, especially in the vicinity of the concentration profile extrema, demonstrate 
consistently that the modeled estimates correspond to somewhat slower diffusion taking place in the modeled system. This might be caused by minor imperfections of the existing mobility databases and the need for some minor adjustments (to be done later), or by an inability to measure the concentrations of light elements reliably $(\mathrm{C}, \mathrm{N})$, thus causing some errors in the assessment of the effective concentrations of iron and other elements; or both. Nevertheless, the trends in all cases have been captured correctly and provide a solid basis for understanding diffusion welding processes in complex systems.

The results obtained for 2 and 3 hours at $1150^{\circ} \mathrm{C}$, as well as for welding at temperatures of $1000^{\circ} \mathrm{C}$, were less satisfactory because the conditions listed here $\left(1500^{\circ} \mathrm{C}, 3600 \mathrm{~s}(1\right.$ hour $\left.), 5 \mathrm{MPa}\right)$ achieved a chromium concentation of $12 \mathrm{wt} \%$, in the nickel foil bond interface area. This gives the nickel interlayer area additional strength and corrosion resistance, as well as keeping process time relatively manageable. Although further testing must be done, particularly of the mechanical, corrosion, and other properties of these joints, the Thermo-Calc/Dictra modeling has indicated useful directions for paring down the actual test matrix, evaluating different interlayer thicknesses (or even different interlayer materials), and other tasks in progress towards a welding specification for this alloy.

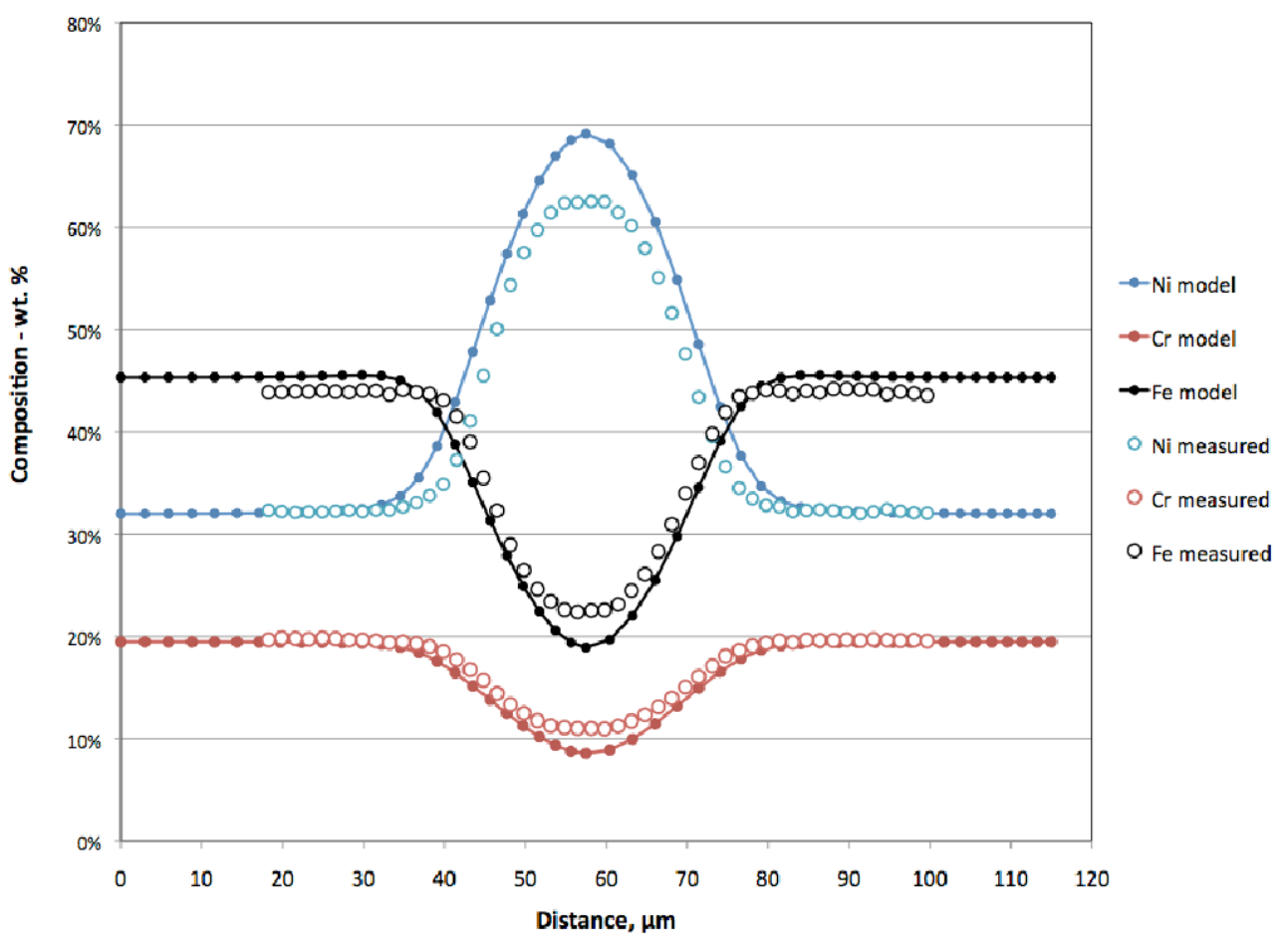

Figure 11. Comparison of model and experimental data (SEM/EDS analyses) for diffusion bonded specimen comprised of Alloy $800 \mathrm{H}$ (15 $\mu \mathrm{m}$ of nickel foil filler) and Alloy $800 \mathrm{H}$. The duration of process was $3,600 \mathrm{sec}$ at compressive pressure of $5 \mathrm{MPa}$ and temperature $1150^{\circ} \mathrm{C}$. Dictra modeling was done for the same conditions.

\subsection{ASME Standards Development}

The IHX is a component that will need to be qualified to the requirements of American Society of Mechanical Engineers (ASME) Boiler and Pressure Vessel Code, Section III, which currently no rules for construction of diffusion welded compact heat exchangers. A diffusion welding procedure will need to be developed that meets the requirements of ASME Section IX, "Welding and Brazing Qualification," ${ }^{24}$ and ASME Section III, Division 5. ${ }^{25}$ Current ASME Code rules for Section VIII, Division 1 are described in Code Cases 2437-1 ${ }^{26}$ and 2621-1. ${ }^{27}$ It should be noted that the approved materials listed in Code Case 2621-1 for 304L(UNS S30403), 316L(UNS 31603), and 2205 Duplex (UNS S31803) may not be 
appropriate choices for diffusion welded, compact heat exchangers for application in nuclear assisted, high temperature industrial process.

A determination on the testing required to meet the requirements of ASME Section III will have to be made through interaction with the following ASME committees: Subgroup on Strength of Weldments (Section II and Section IX); Subgroup on Materials, Fabrication, and Examination (Section III); and Subcommittee on Welding (Section IX). Diffusion welding will be incorporated into ASME Section IX ${ }^{28}$ in an Addenda that will be issued in July 2011. For planning purposes, the following draft essential variables, expected to be included in the Addenda, will be measured in the upcoming work:

- Base metal grade and surface finish

- Filler metal and composition

- Post-weld heat treatment temperature, time, and cooling rate

- Furnace atmosphere

- Preassembly cleaning, block compression, welding time, and temperature.

\section{SUMMARY}

The results of this work indicate that a filler metal is needed for the diffusion welding to achieve good grain growth across the joint which will result in acceptable mechanical properties. The method of application (nickel foil or nickel plating) will need additional optimization work.

The issue of the required vacuum level needs further investigation. Some data show that an overnight pump-down in the Gleeble system achieves a better vacuum which results in less surface oxidation and, in one case, mechanical properties which equaled those obtained with a filler metal addition.

The thermodynamic and diffusion modeling work presented in this paper pursued two interdependent goals: first, to verify that the methods of diffusion modeling implemented in Dictra and the corresponding databases for superalloys-TTFE6 (TTNI8) and MOBFE1 (MOBNI1) - can quantitatively describe the real diffusion couples made of Alloy $800 \mathrm{H}$ and nickel foil filler metal with confidence. The second, more ambitious goal was to use these tools to predict the optimal conditions for diffusion welding of $800 \mathrm{H}$.

Experimental results on concentration profiles of different chemical components in Alloy $800 \mathrm{H}$ (obtained using EDS) match the model reliably. Additional work needs to be done to understand the nature of some discrepancies, especially in the center of the nickel interlayer. After the fundamental work of Campbell et al., ${ }^{8}$ it became clear that very complex multicomponent heterogeneous alloys could be modeled using Dictra. The present work was conducted in order to verify that these tools will serve reliably for the modeling of diffusion welding. This goal was achieved, and the modeling and optimization of diffusion welding for similar and/or dissimilar materials can proceed with confidence.

The second goal was to optimize the welding conditions and reduce the number of experiments. This goal was only partially achieved (established an optimal temperature and time of welding to be 1 hour at $1150^{\circ} \mathrm{C}$ ). Further work is necessary to account for heat-up schedules, plasticity, and creep effects at the process temperature. This will be done using optical imaging microscopy and crystallographic texture analyses, which will be coupled to state-of-the-art plasticity models for this type of material. 


\section{CONCLUSIONS}

Models of diffusion welding in $800 \mathrm{H}$ with a nickel foil interlayer accurately predicted diffusion profiles and provided a quantitative basis for developing experimental matrices. This work demonstrates the applicability and effectiveness of modern thermodynamic and kinetic computational tools that could be used to address many problems in modern physical metallurgy.

Experimentally optimized diffusion welding parameters were able to produce $90+\%$ ultimate tensile strengths in $800 \mathrm{H}$ diffusion welds, with good ductility, indicating that the material can be fabricated into compact heat exchangers for further testing and development.

Techniques were developed for $800 \mathrm{H}$ that can also be applied to other candidate materials for NGNP IHX applications, such as Alloy 617. 


\section{REFERENCES}

1. J. N. Dupont, J. C. Lippold, and S. D. Kiser, Welding Metallurgy and Weldability of Nickel-Based Alloys, John Wiley and Sons, Hoboken, NJ, 2009.

2. M. J. Donachie and S. J. Donachie, Superalloys - a Technical Guide, 2nd edition, ASTM International, Metals Park, OH, 2002.

3. M. G. Nicholas, Joining Processes - Introduction to Brazing and Diffusion Bonding, Kluwer Academic Publishers, Dodrecht, 1998.

4. C. F. Jeff Wu and Michael S. Hamada, "Experiments: Planning, Analysis, and Optimization," Wiley Series in Probability and Statistics, Wiley, NY, 2009.

5. PLN-3565, "Scoping Investigation of Diffusion Bonding for NGNP Process Application Heat Exchangers," Revision 0, Idaho National Laboratory, July 8, 2010.

6. Idaho National Laboratory, "Next Generation Nuclear Plant Project Technology Development Roadmaps: The Technical Path Forward," INL/EXT-08-15148, Revision 0, January 2009.

7. N. Saunders and A. P. Miodownik, CALPHAD (Calculation of Phase Diagrams): A Comprehensive Guide, Oxford and New York, Pergamon, 1998.

8. M. Hillert, Phase Equilibria, Phase Diagrams, and Phase Transformations, Cambridge University Press, Cambridge (2007).

9. Zi-Kui Liu, “A Materials Research Paradigm Driven by Computation,” JOM, October 2009, pp.18-20.

10. C. E. Campbell, W. J. Boettinger, and U. R. Kattner, Acta Mater., Vol. 50, 2002, pp.775-792.

11. Z. -K. Liu and L. -Q. Chen, Applied Computational Materials Modeling: Theory, Experiment, and Simulations, ed. By G. Bozzolo, New York, Springer, 2006, pp.171-213.

12. J. -W. Yoon, F. Barlat, H. Weiland, M. V. Glazoff, and R. E. Dick, State of the Art For Crystal Plasticity Based Modeling, Alcoa Technical Report No. 07-201, 2007. See also: M. V. Glazoff, S. N. Rashkeev, Yu. P. Pyt'ev, J. -W. Yoon and S. Sheu, Appl. Phys. Letts, Vol. 95, 084106, 2009.

13. ASTM B 408-06, "Standard Specification of Nickel-Iron-Chromium Alloy Rod and Bar," ASTM International, West Conshohocken, PA.

14. ASTM E-8/E8M-09, "Standard Testing Methods for Tension Testing Metallic Materials," ASTM International, West Conshohocken, PA.

15 C. Cabet and R. N. Wright, "Corrosion of Intermediate VHTR Heat Exchanger Alloys: Achievements of the US-France I-NERI Program," Paper No. 10226, Corrosion 2010, NACE International, Houston, TX, 2010.

16. ThermoCalc Software AB, Thermo-Calc Classic Version S User's Guide, Pingfang Shi and Bo Sundman, ed., Stockholm, Sweden, 2010.

17. DICTRA Version 25 User's Guide, Thermo-Calc Software AB, Stockholm, Sweden, 2010.

18. A. Borgenstam, A. Engstrom, L. Hoglund, and J. Agren, Journal of Phase Equilibria, Vol. 21, No. 3, 2000, pp.269-280.

19. A. A. Tavasoli and G. Colombe, Metallurgical Transactions A, Vol. 9A, 1978, pp.1203-1211.

20. X. Wang, E. Brunger, and G. Gottstein, Materials Science and Engineering A, Vol. A290, 2000, pp. $180-185$. 
21. A. Czyrska-Filemonowicz and K. Spiradek, Z. Werkstofftechnik, Vol. 14, 1983, pp. 417-421.

22. J. E. Morral, C. Jin, A. Engstrom, and J. Agren, Scripta Materialia, Vol. 34, Issue: 11, 1996, pp. 1661-1666.

23. W. D. Hopfe and J. E. Morral, Acta Metallurgica et Materialia, Vol. 42, Issue 11, 1994, pp. 3887-3894.

24. ASME Boiler \& Pressure Vessel Code, Section IX: “: Qualification Standard for Welding and Brazing Procedures, Welders, Brazers, and Welding and Brazing Operators," 2010.

25. ASME Boiler \& Pressure Vessel Code, Section 111, Division 5. "High Temperature Reactors" (to be issued July 2011)

26. ASME Boiler and Pressure Vessel Code Case 2437-1, "Rules for Diffusion Bonded, Flat Plate, Microchannel Heat Exchanger," Section VIII, Division 1, Approved June 23, 2005.

27. ASME Boiler and Pressure Vessel Code Case 2621-1, "Diffusion Bonding," Section VIII, Division 1, Approved December 14, 2009.

28 . ASME Boiler \& Pressure Vessel Code, Section IX: "Qualification Standard for Welding and Brazing Procedures, Welders, Brazers, and Welding and Brazing Operators," 2010 Edition (2011 addenda, to be issued July 2011) 